\title{
Kalkandelen Para Vakıfları
}

\section{Cash Waqfs of Kalkandelen}

\section{Yakup Ahbab}

Atatürk IIlkeleri ve İnkılap Tarihi Enstitüsü, İstanbul Üniversitesi, İstanbul, Türkiye

\section{Özet}

Vakıf kurumu İslamiyet'in yayılmasıyla ortaya çıkmış sosyal, ictimai ve dini bir kurumdur. İslam tarihi boyunca çeşitli amaçlarla oluşturulmuş vakıflar faaliyet göstermiştir. Bunlardan bir tanesi de Para Vakıflarıdır. Para vakıfları oluşturulduğu bölgenin ekonomik ve sosyal hayatına önemli katkılar sağlamıştır. Para vakıflarının faaliyetleri sayesinde devlet ekonomik olarak rahatlatılmıştır. Kalkandelen'de de para vakıflarının sosyal ve ekonoik hayata olan katkılarını vakıf belgelerinden tespit edilebilmektedir. Bu çalışmada Vakıflar Genel Müdürlüğü Arşivindeki Kalkandelen'e ait para vakıfları incelenmiştir.

Anahtar Kelime: Vakıf, Makedonya, Kalkandelen Para Vakıfları

\section{Abstract}

The Foundation is a social, religious, and religious institution that has emerged with the spread of Islam. Foundations founded for various purposes throughout the history of Islam were active. One of them is cash waqfs. Creating cash waqfs has made important contributions to the economic and social life of the region. The activities of the cash waqfs are relieved by the state. In Kalkandelen, the contribution of poor foundations to social and ecological life can be determined from foundation documents. In this study, cash waqfs of Kalkandelen in the archive of General Directorate for Foundations was examined.

Kay Words: Waqf, Macedonia, Cash Waqfs of Kalkandelen 


\section{Giriş}

Makedonca'da ve bütün Slav dillerinde adı Tetovo, Arnavutça'da Tetove olan Kalkandelen şehri; Üsküp'ün $42 \mathrm{~km}$. batısında, Şar dağları ile Su ha Gora dağları arasında bulunan Polog vadisinde yer alır. Osmanlı dönemi öncesinde bir Sırp bölgesi olan Polog vadisi ve Kalkandelen'de, Osmanlı yönetimi zamanında nüfusun dörtte üçünü çoğunlukla Arnavut, Türk ve Romlar'dan oluşan müslümanlar oluşturuyordu. 1913'ten itibaren müslümanların ve özellikle Türkler'in Türkiye'ye teşvik edilen göçlerine rağmen bu oran XX. yüzyılın sonlarına kadar değişmemiştir. Kalkandelen'deki Müslüman nüfusunun fazlalığı ve bu nüfusun ihtiyaçlarının karşılanması gibi nedenlerden dolayı çeşitli vakıflar oluşturulmuştur. Kalkandelen'deki vakıflar hakkındaki bilgileri vakıflar genel müdürlüğü arşivindeki vakfiye defterlerinden öğrenilmektedir. ${ }^{1}$

Vakıflar, Osmanlı hakimiyeti esnasında Balkanlardaki toplumsal hayatı ilgilendiren birçok alanda uzunca yıllar varlığını etkin bir şekilde sürdürmüştür. Geniş bir vakıf ağıyla donatılmıs, olan sosyal hayatta; dini, siyasi ve içtimai her türlü hizmet insanlara çok rahat ulaştırılmış ve ekonomik açıdan da vakıflar toplumsal hayatta yerini almıştır. Vakıfların bu kadar geniş bir hizmet alanına yayılmasında ahlaki degerlerle birlikte toplumsal gereksinimlerin etkisi oldugu düşünülmektedir. Osmanlı Devleti'ndeki vakıflar ve faaliyet alanları üzerine literatürde pek çok çalışma bulunmaktadır. Ancak bu çalışmalar daha çok vakıf sisteminin işleyişi, dini, tarihi, hukuki ve iktisadi özellikleri gibi konulara odaklanmıştır. Buna karşın Osmanlı'nın kendi içinden tutup çıkardığı bir sistem olan para vakıfları hakkında, tarihi ve felsefi sistemi dışında çok fazla inceleme yapılmamıştır. Gayrimenkulle kurulan geleneksel vakıfların aksine para vakıfları, toplumdaki ihtiyaçların karşılanması, sosyal hizmetlerin yerine getirilmesi esasıyla belli bir sermayeye dayalı kurulmuştur. ${ }^{2}$

Kalkdelen'de mevcut olan para vakıfları iktisadi, sosyal, eğitim-öğretim gibi çeşitli faaliyet alanlarında etkili bir rol almıştır. Bu çalışmada Vakıflar Genel Müdürlüğü arşivinde tespit edilen vakfiyelere dayanarak Kalkandelen' deki para vakıflarının faaliyet alanlarının tespit edilmesi ve bunların tanıtılması amaçlanmıştır.

\section{Para Vakıfları:}

Sözlükte durmak; durdurmak, alıkoymak anlamındaki vakıf (vakf) kelimesi, terim olarak bir malın mâliki tarafından dinî, içtimaî ve hayrî bir gayeye ebediyen tahsisi şeklinde

\footnotetext{
${ }^{1}$ Muhammed Aruçi, "Kalkandelen", DİA, Cilt: 24, 2001 Ankara, s. 262-263; Mehmed İbrahimgil, "Kalkandelen (Tetovo) Alaca-Paşa Camii", Vakıflar Dergisi, XXVI, İstanbul 1997, s. 249-266.

2 Halime Önk, Osmanl Dönemi Para Vakıflarıyla Günümüz Katılım Bankalarının Karşılaştırılması, Afyonkarahisar Üniversitesi, Sosyal Bilimler Enst., Yüksek Lisans Tezi, Afyonkarahisar, 2015, s. 1; Çiğden Gürsoy, Şeyhü'l-İslâm Ömer Hüsâmeddđn Ve Kazasker Mehmed Vahid Efendilerin Para Vakıflarına Dair Mesihat Arşivindeki 1698 Numaralı Defterđn Değerlendirilmesi, İstanbul Üniversitesi Sosyal Bilimler Enst., Yüksek Lisans Tezi, İstanbul 2011, s. 1-10.
} 
teşkil edilen hayır müessesesini ifade eder. ${ }^{3}$ Vakıf; süreklilik, devamlılık ve faydacılık ilkeleri doğrultusunda oluşturulmasına karar verilen kuruluşunda kişisel hiç bir maddi menfaat gözetilmeyen, çıkar sağlanması düşünülmeyen şahsî, dünyevî ve uhrevî İslami bir kurumdur. ${ }^{4}$

$\mathrm{Bu}$ açıdan bakıldığında devlete ait sosyal hizmetler ve bazı kamu harcamaları gibi ekonomik külfetleri üzerine alarak devletin yükünü hafifletmiş ve ona, gelirini daha mühim ve hayatî sâhalarda sarf etmek imkânı vermiştir. ${ }^{5}$ Ayrıca vakıflar vakfiyesinde faaliyetleri yerine getirmek için istihdam sahası açmış ve iş imkânlarının sağlanmasında etkili olmuştur. ${ }^{6}$

İslam tarihi boyunca kuruluş amacına göre çeşitli vakıflarla karşılaşılmaktadır. Bunlardan bir tanesi de fikhi açıdan İslama uygunluğu hala güncel ve tartışmalı olan, İslam ulemasının üzerinde çeşitli görüşler öne sürdüğü, hüküm ve fetvalar verdiği para vakıflarıdır. Bu vakıfların kayıtlı olan sermayesini nakit para teşkil etmektedir. Bu vakıfların çalışma usulü vakfedilen paranın vakfiyesindeki kurallar uyarınca değerlendirilmesiyle elde edilen kârların/faizlerin vakfın faaliyetlerine uygun bir şekilde kullanılmasından ibarettir. Diğer bir ifadeyle para vakıflarında vakfedilen nakit para, yatırım aracı ve uzun vadeli bir kaynak, fon olarak kullanımıştır. ${ }^{7}$ Yukarıda da ifade

3 Mehmet Hacı Günay, "Vakıf", DIA, cilt: 42, İstanbul 2012, sayfa: 475-479; http://www.isbek.org/node/vakfiyelerde-dua-ve-beddualar.html Erişim Tarihi: 10. 06. 2017; Ayrıca bkz. Nazif Öztürk, Elmalılı M. Hamdi Yazır gözüyle vakıflar: Ahkâmu'l-evkaf, Türkiye Diyanet Vakfı, Ankara 1995; Nazif Öztürk, Menşe'i ve Tarihi Gelişimi Açısından Vakıflar, Vakıflar Müdürlüğü Yayınları, Ankara 1983; Nazif Öztürk, Türk Yenileşme Tarihi Çerçevesinde Vakıf Müessesesi, Türkiye Diyanet Vakfı Yayınları, Ankara 1995; A. Himmet, Vakfa Dair Yazılan Eserlerle Vakfiye ve Benzeri Eserler, Ankara 1965; Ali Himmet Berki, Vakfa Dair Yazllan Eserlerle Vakfiye Ve Benzeri Vesikalarda Geçen Istılah Ve Tâbirler, Vakıflar Gen. Müd. Neş., Ankara 1966; http://www.isav.org.tr/img/20131030_4127313495.pdf Erişim Tarihi: 10. 06. 2017; Osman Gazi Özgüdenli, "Vakfiye”, DİA, İstanbul 2012, cilt: 42, sayfa: 465-467; Ali Himmet Berki, "Vakıfl arın Hukuk ve Tarih Bakımından Kıymeti", Vakıflar Dergisi, sayı: 6, İstanbul 1965, s. 5-9.

4 Bkz. Al-i İmran suresinin 92. Al-i İmran,
3/92: http://arsiv.diyanetvakfi.org.tr/meal/Aliimran.htm Erişim Tarihi: 10. 06. 2017

${ }^{5}$ Vakıfların Osmanlı Devleti'ndeki sosyla ve okonomik hayata dair faydaları içün bkz: Mustafa Armağan, "Osmanlı, Bir Vakıf Medeniyeti", Sivil Toplum Düşünce ve Araştırma Dergisi, sayı: 15, İstanbul 2006, s. 169-171; İbrahim Erol Kozak, Bir Sosyal Siyaset Müessesesi Olarak Vakıf, Akabe Yayınları, İstanbul 1985; Vakıfların tarihi ve hukuki mahiyeti hakkında daha fazla bilgi için bkz: Ali Himmet Berki, "Vakıfların Tarihi, Mahiyeti, İnkişafı ve Tekâmülü, Cemiyet ve Fertlere Sağladığı Faideleri", Vakıflar Dergisi, sayı: 6, İstanbul 1965, s. 9-15.

${ }^{6}$ Methiye Gül Çöteli, "İslam Kentinde Vakıfların Ticaret Bölgesinin Oluşumu Üzerine Etkisi: Hayrat-Akar İlişkisinin Döngüsel Doğası", Vakıflar Dergisi, sayı: 45, Haziran 2016, s. 9-28; Tevfik Güran, Ekonomik ve Mali Yönleriyle Vakıflar: Süleymeniye ve Şehzade Süleyman Paşa Vakıfları, Kitabevi, İstanbul 2006; s. 1-15.

7Para vakıfları ile ilgili Osmanlı ulemaları çeşitli görüşler ortaya koymuştur. Bunlar için bkz. Tahsin Özcan, "İbn Kemal'in Para Vakıflarına Dair Risâlesi", İslâm Araştırmaları Dergisi, sayı: 4, İstanbul 2000, s. 31-41; Tahsin Özcan, "Sofyalı Bâlî Efendi'nin Para Vakıflarıyla İlgili Mektupları", İslâm Araştırmaları Dergisi, İstanbul 1999, s. 125-155; Mehmet Şimşek, "Osmanlı Cemiyetinde Para 
edildiği üzere bu vakıflarda nakit para çeşitli şekillerde kullandırılmasıyla- Para vakıfları sermayesi olan nakit parayı üç çekilde işletirdi. Bunlar kâr ve zararın ortak olunduğu Mudaraba; verlien sermayaye karşılık kârın tamamının bir kişi tarafından alınması işlemine Bidaâ ve son olarak da eldeki sermayeyi önceden belirlelen bir oranda değerlendirilmesi olan Muamele- $i$ Şer'iyye (Murabaha)'dır- vakıf ömrünün nisbeten uzatılması amaçlanmıştır. ${ }^{8}$ Para vakıflarının ihtiyaç sahiplerine verdiği maddi destek ile iktisadi açıdan ülkenin ekonomik/finansal kalkınmasına vakfiyelerde belirlenen çerçevelerde katkı sağlamış ve bu vakıflar ekonomik hayatın bir parçası haline gelmiştir. ${ }^{9}$

Para vakıfları sermayesini oluşturduğu nakit parayı, Karz-ı Hasen, Mudabara, Murabaha ve Bidaa gibi şekillerde değerlendirilmiş, bu faaliyetlerden elde edilen gelir vakfiyedeki şartlara göre kullanılmıştır. Para vakıflarında sermayenin kullandırılmasında en fazla tercih edilen usul ise murabahadır. Murabaha yönteminde vakfın nakit parası piyasa rayiçleri gözetilerek, yıllık \% 10-15 gibi kâr/faiz oranıyla kullandırılmıştır. Ülke genelindeki vakfiyelerdeki kayıtlara göre, vakfedilen paraların işletilmesinde faiz oranları genelde $\% 10^{\prime}$ dur, istisnai hallerde bu oran $\% 7^{\prime}$ ye kadar düşebilmekte ya da \%15'e kadar çıkabilmektedir. Nemalandırma müddeti ise bir yıl ile üç yıl arasında değişebilmektedir. Para vakıfları alışılmışın dışında, vakfın gayrimenkul malını değil parasını vakfetmesiyle gerçekleşen bir vakıf türü olduğu için diğer vakıflarda olduğu gibi para vakıflarında da cayma söz konusu olamaz ve vakfedilen para ebedi olarak vakıf olarak kullanılır, paranın vakıf yöneticileri tarafından

Vakıfları Üzerinde Münakaşalar", Ankara Üniversitesi İlahiyat Fakültesi Dergisi, sayı: 27/1, s. 207220; Kâş̧if Hamdi Okur, "Para Vakıfları Bağlamında Osmanlı Hukuk Düzeni ve Ebussuud Efendinin Hukuk Anlayışı Üzerine Bazı Değerlendirmeler", Gazi Üniversitesi Çorum İlahiyat Fakültesi Dergisi, 2005/1-2, cilt: IV, sayı: 7-8, s. 33-58; Ahmet Hamdi Furat, "İslam Hukukunda Vakıf Akdinin Bağlayıcılığı", Istanbul Üniversitesi Ilahiyat Fakültesi Dergisi, 2012, Vol. 27, s. 61-84. 24p; İrfan Türkoğlu, "Osmanlı Devletinde Para Vakıflarının Gelir Dağılımı Üzerindeki Etkileri", Süleyman Demirel Üniversitesi Iktisadi ve Idari Bilimler Fakultesi Dergisi, y1l: 2013, cilt: 18, sayı: 2, s. 187-196; Selim Hlmi Özkan, "Bir ilim ve Kültür Şehri: Sofya", Balkanlar'da Osmanlı Mirası ve Defter-i Hakani, C. I, Libra Yayınları, İstanbul, 2015, s. 387.

8 Halime Önk, a.g.t., s. 15-17; Cantürk Kayahan -İrfan Görkaş, Osmanlı Dönemi Bölgesel Kalkınmanın Finansman Aracı Olarak Para Vakıflarının Kullanımı, Muhasebe Ve Finansman Dergisi, sayı: 44, İstanbul 2009, s. 212-227; Tahsin Özcan, Osmanlı Para Vakıfları, Kanuni Dönemi Üsküdar Örneği, s. 50-55.

${ }^{9}$ Nazif Öztürk, "Sosyal Siyaset Açısından Cumhuriyet Öncesi Vakıfları", Cumhuriyetin 80.Yılında Uluslararası Vakıf Sempozyumu Kitabı, Vakıflar Genel Müdürlüğü Yayınları, Ankara 2004, s. 35-47; Havva Selcen Yaşar, XIX. Yüzyıl Uşak Para Vakıfları, Dokuz Eylül Üniversitesi Sosyal Bilimler Enstitüsü, Yüksek Lisans Tezi, İzmir 2017, s. 34-35; Ayrıca bkz. Tahsin Özcan, Vakıf Medeniyeti ve Para Vakıfları, Türkiye Finans Kültür Yayınları, İstanbul 2010; Nasi Aslan, “Osmanlı Toplumunda Para Vakıflarının Kurumsallaşmasında Rol Oynayan Faktörler", Din̂̂ Araştırmalar, Eylül-Aralık c. I, c. 2, Ankara 1998; http://www.islamveihsan.com/sadaka-i-cariye-nedir.html Erişim Tarihi: 10. 06. 2017; Mehmet Bayyiğit, "Sosyal Yardımlasma Ve Dayanısma Kurumu Olarak Vakıflar", Selçuk Üniversitesi İlâhiyat Fakültesi Dergisi, Bahar, sayı: 11, Konya 2001, s. 59-67; Değer Alper -Canan Erdoğan, "16. Ve 18 Yy. Arasında Bursa Para Vakıfları Ve Bursa Ekonomisine Etkileri", Uludăg Üniversitesi İktisadi ve İdari Bilimler Fakültesi Dergisi, cilt: XXVIII, sayı: 1, 2009, s. 85-99. 
işletilmesiyle elde edilen gelir, vakfın kuruluş amacı doğrultusunda harcanırdı. ${ }^{10}$

Para vakıfları, belirli bir kâr oranıyla işlem yaptıklarından yani faizle çalışmlarından dolayı İslam âlimleri arasında tartışmalı bir konu olmuştur. Bu tartışmalar özellikle Osmanlı döneminde artmış ve gündem teşkil eden bir konu halini almıştır. Para vakıflarının caizliği üzerindeki tartışmalar ilk defa Anadolu Kazaskeri Çivizade Mehmet Muhyiddin Efendi ile Rumeli Kazaskeri Ebussuud Efendi arasinda başlamıştır. Çivizade, para vakfının caiz olmadığını ileri sürerek olumsuz fetva vermiştir. Bu görüşü benimseyen İmam Birgivi Mehmet Efendi de nakit para vakfının caiz olmadığını ve bu işlemlerin faiz olduğu fikrini ileri sürmüştür. Birgivi bu fetvasını verirken para vakıfları için ayet ya da hadis olmaması nedeniyle verdiğini açıklamıştır. ${ }^{11}$

Şeyhülislamı Ebussuud Efendi ise para vakıflarının caiz olduğunu ileri sürmüştür. $\mathrm{Bu}$ fetvayı verirken de bu tür kurumların halkın yararı için kurulmuş olduğunu ve bunun için faaliyetlerde bulunduğunu belirterek bu gibi hayır kurumlarının yok edilerek ortadan kaldırılmasıyla asırlarca oluşturulmuş olan düzenin bozulmaması gerektiği şeklinde izah etmiştir. Bu tartışmalı konuya bir izahat getirmek için de bir risale kaleme almıştır. Anlaşılan o ki Ebussuud Efendi bu fetvayı vermesinden maksadı, mevcud bulunan böyle faydalı bir müessesenin devamını sağlamaktı. Ebussuud Efendi görüşünde hanefi fıkıhçılarından İmam Züfer, el-Sera si ve Burhanu'd.din 'Ali gibi önde gelen İslam alimlerinin fıkhi görüşlerinden istifade etmiştir. Para vakıflarının caiz olduğunu savunun bir diğer İslam âlimi de Kemal Paşa-zade'dir. Konuyla alakalı kaleme aldığı risalesinde daha çok kendisinden önce konuyla alakalı fetvalar veren Fahruddin Kadihan ve İmam Züfer'in para vakıflarının caizliği üzerine vermiş oldukları görüşleri aktarmıştır. ${ }^{12}$

Para vakıflarının yaygınlaşmasında en önemli etken Ebussuud Efendi'nin bu tür kurumların caiz olduğuna dair yapmış olduğu ictihadıdır. Ebussuud Efendi bu vakıfların işlemleri sırasında almakta oldukları kâr/faiz oranını \%15 ile sınırlamış ve bu oranın üzerinde bir kâr payı ile işlem yapılmasının ise caiz olamayacağına dair fetvasıyla para vakıflarının fıkhi temellerini atmış ve meşruiyetini ortaya koymuştur. Diğer taraftan da para vakfının lehine emir çıkarılmasında etkili olarak bağlayıcılık kazanmasını sağlamıs,tır. ${ }^{13}$

10 İrfan Türkoğlu, "Osmanlı Devletinde Para Vakıflarının Gelir Dağılımı Üzerindeki Etkilerı", Süleyman Demirel Üniversitesi Iktisadi ve İdari Bilimler Fakültesi Dergisi yıl: 2013, cilt: 18, sayı: 2, s. 187-196.

${ }^{11} \mathrm{http}: / /$ www.enfal.de/oe84.htm Erişim Tarihi: 10. 06. 2017

12 Mehmet Şimşek, "Osmanlı Cemiyetinde Para Vakıfları Üzerinde Münakaşalar", Ankara Üniversitesi İlahiyat Fakültesi Dergisi, sayı: 27/1, s. 211; Tahsin Özcan, “İbn Kemal'in Para Vakıflarına Dair Risâlesi", İslâm Araştırmaları Dergisi, sayı: 4, İstanbul 2000, s. 31-41; Selim Hilmi Özkan, "Bir Muhalefet Olarak İmam Birgivi ve Sosyal Hayata Etkileri", Uluslararası Balıkesir'e Değer Katan Şahsiyetler Sempozyumu Bildirileri, Karesi Belediyesi Kültür Yayınları, Balıkesir, 2014, s. 384 .

13 Şebahattin Usta, "Trabzon Para Vakıfları", Karadeniz İncelemeleri Dergisi, 2016; (20): 55-76; Muhammed Emid Durmuş, Muhasebe Kayıtları Işı̆̆ında 18. Yüzyılın Son Ceyreğinde Üsküdar Para Vakıfları, Sakarya Üniversitesi Sosyal Bilimler Enstitüsü, Yüksek Lisans Tezi, Sakarya 2016, s. 53. 
Anlaşılan o ki para vakıflarına İslama uygunluğu açısından cevaz veren alimeler genel olarak bu tür vakıfların toplumsal ihtiyaçların karşılanmasındaki faydalarını göz önünde bulundurmuş ve buna göre olumlu görüş beyan etmişlerdir. Bu vakıflar hakkında olumsuz görüş beyan eden âlimler ise buralarda uygulanan faizli muameleler konusu üzerinde durmuş ve buna göre fetvalar vermişlerdir. Osmanlı Devleti ise bu tür vakıfların faaliyetlerine karşı çıkmamıştır. Bunda vakıf faaliyetleri neticesinde hem ekonomik hem de sosyal hayata olan katıkıları önemli bir paya sahiptir. ${ }^{14}$

Para vakıfları üzerinde yapılan tarışmaların bir benzeri de günümüzde İslami finans kurumları üzerinden devam etmektedir. Günümüzde de bir kısım İslam âlimi bu kurumların caiz olduğunu savunurken bir kısmı de faizle işlem yapıldığını, bir anlamda parayla paranın satın alındığını ileri sürerek bu tür kurumlardan kredi almanın fıkhi açıdan sakıncalı, caiz olmadığını savunmaktadır. ${ }^{15}$

Anlaşılacağı üzere para vakıfları üzerinde yapılan tartışmalar uzun yıllar aynı minvalde devam etmiş, her iki görüşü savunanlar kendilerince deliller ortaya koymuş fakat tartışmalar devam ede gelmiştir. Fıkhi uygunluğunu bir kenara bırakılırsa o günlerden bu yana ihtiyaç sahibi insanların bu tür finans kaynaklarına olan ilgisi azalmamış, artarak devam edegelmiştir.

\section{Kalkandelen Para Vakıfları:}

Kalkandelen'de para vakıfı kurmak isteyen hayırseveler hazırlamış oldukları şartların yazılı olduğu bir vakfiye metnini kadının onayına sunardı. Kadının bu yazılı metni onaylamasının ardından vakıf kurulmuş olurdu. ${ }^{16}$ Hayırseverin malımı vakf ettim, habsetttim, tasadduk ettim veya sadaka-i müebbede ile sadaka ettim, vakf- $\iota$ mü'ebbed ve habs-i muhalled kıldım gibi vakfa işareteden ifadelerin zikredilmesiyle vakıf işlemi gerçekleşmiş olmaktaydi. ${ }^{17}$

${ }_{14}$ Mehmet Bulut and Cem Korkut, "Finansal İstikrar Ve Para Vakıfları Etkisi: Rumeli Para Vakıfları Örnekleri", MPRA Paper No. 73902, posted 24 September 2016 19:05 UTC;

https://mpra.ub.uni-muenchen.de/73902/1/MPRA_paper_73902.pdf Erişim Tarihi: 10. 06. 2017

${ }^{15}$ Finans Kuruluşları üzerine çeşitli görüşler için bkz: Güncel Dini Meseleler İstişare Toplantısı II, Yay. Hazırlayan Mehmet Bulut, Diyanet İşleri Başkanlığı Din İşleri Yüksek Kurul Başkanlığı, Ankara 2008.

${ }^{16}$ İsmail Kurt, Para Vakıfları -Nazariyat Ve Tatbikat-, İslâmî İlimler Araştirma Vakfi, İstanbul 2006, s. 110; İsmail Kurt, "İstanbul Para Vakıfları", Türk Dünyası Arastırmaları Dergisi, sayı: 101 , İstanbul 1996, s. 65-96; Halime Önk, a.g.t., s. 9-15; Cafer Çiftçi, “18.yy da Bursa'da Para Vakıfları ve Kredi İşlemleri", Ankara Üniversitesi Dil ve Tarih-Coğrafya Fakültesi Tarih Bölümü Tarih Arastırmaları Dergisi, cilt: 23., sayı: 36, Ankara 2004, s. 79-102; Hamza Keleş, “Osmanlılarda 19. Yüzyıldaki Para Vakıflarının İşleyiş Tarzı ve İktisadî Sonuçları Üzerine Bir Çalışma -Karacabey (Mihaliç) Kazası Örneği", G.Ü. Gazi Eğitim Fakültesi Dergisi, cilt 21, sayı: 1, 2001, 189-207; Bahaeddin Yediyıldız, XVIII. Yüzyılda Türkiye'de Vakıf Müessesesi Bir Sosyal Tarih İncelemesi, TTK, Ankara 2003, s. 110-120; Tahsin Özcan, Osmanlı Para Vakıfları, Kanuni Dönemi Üsküdar Örneği, TTK, 2003 Ankara, s. 53; İsmail Kurt, Para Vakıfları-Nazariyat Ve Tatbikat-, s. 111.

${ }_{17}$ Bahattin Turgut, Urfa Vakıfları (1850-1900), Marmara Üniversitesi Sosyal Bilimler Enst., Doktora Tezi, İstanbul 2013, s. 11; Ziya Kazıcı, Osmanlı'da Vakıf Medeniyeti, Kayıhan Yayınları, İstanbul 
Tablo 1: Kalkandelen Para Vakıfları

\begin{tabular}{|c|c|c|c|c|}
\hline Vakfın Adı & Bulunduğu Yer & \begin{tabular}{|l|} 
Sermayesi \\
-Kuruş-
\end{tabular} & $\begin{array}{l}\text { Yillık Faiz } \\
\text { Oranı }\end{array}$ & Tescil Tarih \\
\hline Âdem bin Sinan ${ }^{18}$ & Sedlerce-i Bala Köyü & 2000 & $\% 15$ & 18.03.1901 \\
\hline Ahmed Efendi ibn Hamid ${ }^{19}$ & Köprü Mahallesi & 500 & - & 20.07 .1909 \\
\hline Davud Ağa ${ }^{20}$ & Nebruştan Köyü & 4000 & $\% 15$ & 09.04 .1901 \\
\hline Emin Ağa bin Seyfullah ${ }^{21}$ & Gostivar Nahiyesi & 100 & $\% 15$ & 03.11 .1903 \\
\hline Hasbi Efendi Bin Nebi Ağa22 & Cedîd Mahallesi & 1000 & $\% 15$ & 07.04 .1910 \\
\hline İlyas Ağa ibn İsmail ${ }^{23}$ & Sedlarça-i Bala Köyü & 1000 & $\% 15$ & 05.06 .1906 \\
\hline Recep Ağa bin Ali²4 & Beştime-i Bala Köyü & 500 & $\% 15$ & 17.03.1909 \\
\hline Rifat bin Bayram ${ }^{25}$ & Brodeç Köyü & 1000 & $\% 15$ & 28.11 .1901 \\
\hline Bekir Bin Süleyman²6 & Gostivar Nahiyesi & 1000 & $\% 15$ & 01.10 .1903 \\
\hline Emrullah Ağa İbn Receb ${ }^{27}$ & Gostivar Nâhiyesi & 1000 & $\% 15$ & 05.02 .1908 \\
\hline Hasan Ağa ibn Süleyman ${ }^{28}$ & Lakoviç Köyü & 2000 & $\% 15$ & 05.03 .1895 \\
\hline \begin{tabular}{llrr} 
Kamil bin & \multicolumn{2}{c}{ Zeynel } & ve \\
Muharrem bin & Arif ve & Bilal \\
bin Salih ve & Şaban & bin \\
Adnan ${ }^{29}$ & & &
\end{tabular} & Gavrance Köyü & 2000 & $\% 15$ & 16.11.1887 \\
\hline Mustafa bin Kanber ${ }^{30}$ & Gervul Köyü & 2500 & - & 30.11 .1899 \\
\hline Süleyman Bin Faris ${ }^{31}$ & Vibçe Köyü & 4000 & $\% 15$ & 09.09 .1908 \\
\hline Yunus Ağa ibn Muslih ${ }^{32}$ & Gostivar Nâhiyesi & 2700 & $\% 15$ & 07.09.1901 \\
\hline
\end{tabular}

2003, s. 40-50; Hayrettin Karaman, Anahatlarıyla İslam Hukuku-2, Ensar Neşriyat, İstanbul 2016, s. 215-220.

${ }^{18}$ VGMA, Defter nr: 991, sayfa: 31.

${ }^{19}$ VGMA, Defter nr: 990, sayfa : 43.

${ }^{20}$ VGMA, Defter nr: 989, sayfa: 227.

${ }^{21}$ VGMA, Defter nr: 990, sayfa: 156.

22 VGMA, Defter nr: 990, sayfa: 95.

${ }^{23}$ VGMA, Defter nr: 989, sayfa: 226.

${ }^{24}$ VGMA, Defter nr: 990, sayfa: 31.

${ }^{25} V G M A$, Defter nr: 990, sayfa: 73.

${ }^{26}$ VGMA, Defter nr: 990, sayfa: 52.

27 VGMA, Defter nr: 991, sayfa: 40.

${ }^{28}$ VGMA, Defter nr:: 989, sayfa: 113.

${ }^{29}$ VGMA, Defter nr: 988, sayfa: 278.

${ }^{30}$ VGMA, Defter nr: 989, sayfa: 193.

${ }^{31}$ VGMA, Defter nr: 990, sayfa: 91.

${ }^{32}$ VGMA, Defter nr: 991, sayfa: 49. 
Vakıflar Genel Müdürlügü Arşivinde Kalkadenlen'e ait on beş adet para vakfının varlığını tespit edilmiştir. Kalkandelen'deki on beş para vakfının toplam sermayesi 25.300 kuruştur. Bu vakıflardan Kalkandelen merkezinde üç adet bulunurken geriye kalan on iki para vakfı ise Kalkandelen'e bağlı köy ve nahiyelerde bulunmaktaydı. Kalkandelen merkezindeki vakıflar, Hasbi Efendi bin Nebi Ağa ve Ahmed Efendi ibn Hamid vakıflarıdır. Bu vakıfların toplam sermayesi 1. 500 kuruştur. Bu da Kalkandelen para vakıflarının toplam sermayesinin neredeyse \%6'sına tekabül etmektedir. Kalkandelen'e bağlı köy ve nahiyelerdeki para vakıflarının sermayesinin toplamı 23.800 kuruştur. Bu da Kalkandelen'deki toplam para vakıfları sermayesinin \%94'üne denk gelmektedir.

Kalkandelen para vakıflarının toplam sermayesi yukarıda da ifade edildiği üzere 25.300 kuruştur. Bu vakıflar içerisinde en büyük olanı Kalkandelen'e bağlı Nebruştan Köyünde yörenin ileri gelenlerinden olduğu anlaşılan hayırsever Davud Ağa tarafından kurulmuştur. Bu vakfın vakfiyesi 9 Nisan 1901 tarihinde Kalkandelen Bidayet Mahkemesi tarafından tescil edilmiştir. Bir diğer vakıf ise yine Kalakandelen'e bağlı Vibçe Köyünde hayırsever Süleyman ibn Faris tarafından 9 Eylül 1908 tarihinde vakfiyesi tescil edilen Süleyman ibn Faris vakfıdır. Bu iki para vakfının sermayesi 4.000'er kuruş olup toplam sermayeleri 8.000 kuruştur. Bu iki para vakfı Kalkadenlen para vakıfları sermayesinin \% 32'sini oluşturmaktadır. Emin Ağa bin Seyfullah vakfı ise şehirdeki en küçük sermayeli para vakfıdır.

Kalkandelen para vakıfları ülkenin diğer büyük şehirlerdeki para vakıflarıyla karşılaştırıldığında çok küçük vakıflar olduğu anlaşılmaktadır. Örneğin bu dönemde Üsküp'te toplam yedi para vakfı tespit edilmiş ve bunları 3'ü Üsküp merkezde yer alırken $4^{\prime}$ ü de kırsalda kurulmuş vakıflara aittir. Kaçanikli Mehmed Paşa, Ušküp şehrinin merkezinde ve kırsal bolgelerinde menkul, gayrimenkul birçok varlığnı vakfa bağışlarken, sahip oldugu 1.200 .000 akçe değerindeki 10.000 altınını da vakfetmiştir. Yine Adana'da kurulan 29 vakıf bünyesinde vakfedilen para 5.614 .320 akçe, Sivas'ta XVIII. Yüzyıldan XIX. yüzyılın ikinci yarısına kadarki 150 yıllık sürede 34 para vakfı olup, vakfedilen toplam para 40.160,5 kuruştur. ${ }^{33}$ Rumeli'nin en önemli ticaret merkezlerinden biri olan Selanik'te ise 1696-1766 yılları arasında para vakıfları sayısı 233 adet olup toplam sermayeleri 32.742.207 akçedir. ${ }^{34}$

Kalkandelen para vakıflarının tamaminın kurucusu erkek olup kadın vakıf kurucusuna rastlanılmamıştır. Bu durum da erkeğin Kalkandelen'deki ekonomik hayata olan katkısının ne kadar çok olduğunu göstermektedir.

Kalkandelen'deki para vakfı kurucularının sosyal statülerine bakıldığında ise vakıf kurucularının sekiz tanesinin ağa lakabını kullandığı ve toplumun üst sınıfından olduğu anlaşılmaktadır. Geri kalan yedi vakıf kurucunun ise herhangi bir lakabı veya ünvanı

${ }_{33}$ Mevlüt Dede, Üsküp Vakıfları-Bir Sosyal Tarih İncelemesi- Gazi Üniversitesi Sosyal Bilimler Enstitüsü, Doktora Tezi, Ankara 2015, s. 69; Ayrıca bkz: Mustafa Alkan, Adana Para Vakıfları İnsan, Vakıf ve Şehir, TTK, Ankara 2014, s. 170-175; Ömer Demire, Sivas Şehir Hayatında Vakıfların Rolü, TTK, Ankara 2000, s. 120-130.

${ }^{34}$ H. Veli Aydın, "Selanik'te 18. Yüzyılın İlk Yarısında Para Vakıfları ve Kredi İşlemleri", Tarih Incelemeleri Dergisi, XXIX / 1, 2014, s. 87-106. 
olmadığı için bu kişilerin toplum içerisindeki sosyal konumları hakkında bilgi sahibi olunamamıştır.

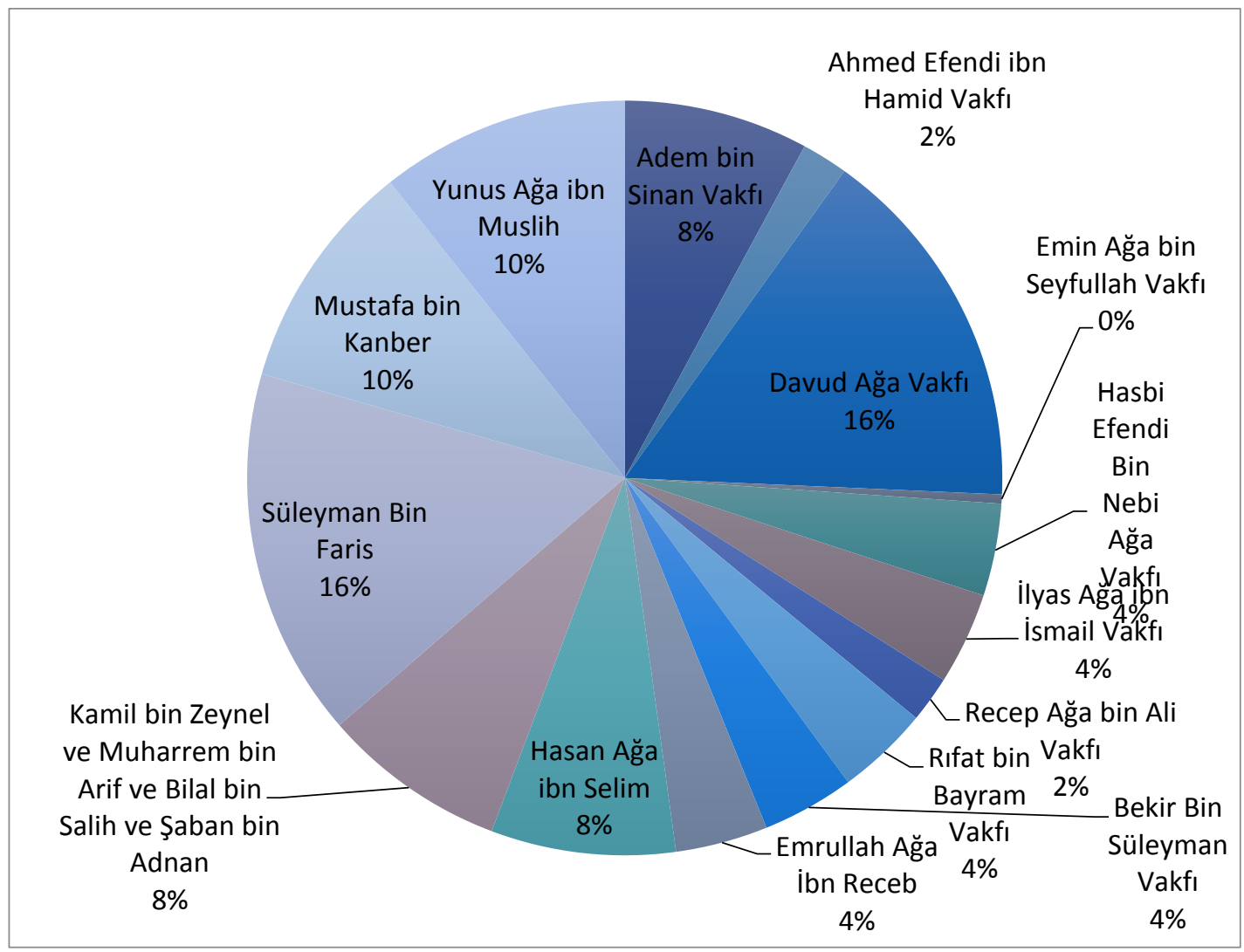

Grafik 1: Sahip Oldukları Sermayelere Göre Kalkandelen Para Vakıflarının Oransal Dağılımı

\section{Kalkandelen Para Vakıflarının İdaresi ve Tevliyetleri:}

Vakıf hizmetlerinin aksamadan yerine getirilmesi için bu kurumlarda çeşitli personel istihdam edilmiştir. Bu personellerin idare edilmesinden ve vakfın yönetilmesinden sorumlu kişiye mütevelli bu görevlendirmeye de tevliyet denirdi. Mütevellinin belirlenmesinde hayırseverin istek ve tercihi etkili olmakta, herhangi bir mahzuru olmaması durumunda da kadı bunu onaylamaktaydı. ${ }^{35}$

Kalkandelen para vakıflarının on üç tanesinde vakfın idarecisi olan mütevelli hayırseverin bizzat kendisidir. Mütevellinin bizzat vakıf kurucusunun olmadığı vakıflar

${ }^{35}$ Nazif Öztürk, Mütevelli, DİA, cilt: 32, 2006, s. 217-220; Osman Ergin, Türkiye'de Şehirciliğin Tarihi İnkişafı, İstanbul Üniversitesi Hukuk Fakültesi İktisat ve İctimaiyat Enstitüsü Neşriyatı, İstanbul 1935, s. 72-73; Havva Selcen Yaşar, a.g.t., s. 18; Tahsin Özcan, “Osmanlı Toplumuna Özgü Bir Finansman Modeli: Para Vakıfları”, Çerçeve, yıl: 16, sayı: 48, Ekim 2008, s. 124-128; Tahsin Özcan, "Para Vakıflarıyla İlgili Önemli Bir Belge", İlam Araştırma Dergisi, III/2, TemmuzAralık 1998, s. 107-112; Bahaeddin Yediyıldız, a.g.e., s. 175-185; http://www.isbek.org/node/vakfiyelerde-dua-ve-beddualar.html Erişim Tarihi: 10. 06. 2017 
ise sadece iki tanedir. Bunlar Ahmet Efendi bin Hamid ve Hasbi Efendi bin Nebi Ağa vakıflardırı. Bunlardan Ahmed Efendi bin Hamid para vakfında mütevelli olarak Çarşı Bala medreresi müderrislerinden Abdullah Efendi vakıf kurucusu tarafından seçilmiş ve kadı da hayırseverin bu isteiğini onaylamıştır. Vakfiyenin şartlarına göre de Mütevelli Abdullah Efendi'nin vefatınıdan sonra kimin mütevelli olacağı da belirtilmiştir. Buna göre mütevelli Abdullah Efendi'nin vefatının ardından yine aynı medresede görev yapacak olan müderris vakfın mütevellilik görevini üstelnecektir. Hasbi Efendi Bin Nebi Ağa para vakfında ise Yunus Efendi ibn Hacı Numan Ağa adında bir kişi hayırsever Hasbi Efendi bin Nebi Ağa taraafından mütevelliliğe getirilmiştir. Yunus Efendi'den sonra vakfın mütevelliliğine ise kimin geçeceği belirtilmemiştir.

Kalkandelen para vakıflarında vakıf kurucusunun vefatından sonar onun evlatlarının onlardan sonra da torunlarının vakfın tevliyetine şart koşulduğu anlaşılmaktadır. ${ }^{36} \mathrm{Bu}$ tür aile vakıflarının Kalkandelen para vakıflarına oranı ise \% 20 'dir. Bunlar Hasan Ağa ibn Süleyman, Mustafa bin Kanber, Kamil bin Zeynel ve Muharrem bin Arif ve Bilal bin Salih ve Şaban bin Âdem vakıflarıdır.

Kalkandelen'de Hayırsever Hasan Ağa ibn Süleyman para vakıf vakfiyesine göre vakfından elde edilecek gelirlerden bir kısmının (300 kuruş) Kalkandelen kazasına tabi Lakoviç Köyündeki camide görevli olan hatibe verilmesini şart koşmuştur. Yine diğer aile vakfiyelerinde gördüğümüz üzere hayırsever Hasan Ağa ibn Süleyman ... Ve ben ber hayat oldukça vakf-ı mezkûrun tevliyeti bana ve vefatımdan sonra batnen ba'de batnin evlâdı ve evlâd-ı evlâdı zükurumun ekber ve erşedine ve ba'de'l-inkiraz tesviyye-i mezkûre karye-i mezbûre ahalisinin beynlerinde müsehhab ve muhtarları olan kimesneye meşruta ola... diyerek kendisini mütevelli tayin ettirmiş ve tevliyetin kendisinin vefatından sonra da en büyük ve aklı başında olan evladına, ondan sonra da torununa geçmesini şart koşmuştur. ${ }^{37}$

Aşağıdaki tabloda Kalkandelen para vakıflarındaki mütevellilerin kimlerden olduğu ve mütevellinin vefatından sonra vakfı kimin idare edileceği gösterilmiştir.

Tablo 2: Kalkandelen Para Vakıflarında Tevliyet

\begin{tabular}{|c|c|c|c|}
\hline Vakıf & $\begin{array}{l}\text { Tevliyeti } \\
\text { Kendine }\end{array}$ & $\begin{array}{c}\text { Tevliyeti Evlat ve } \\
\text { Torunlarına }\end{array}$ & $\begin{array}{l}\text { Tevliyeti } \\
\text { Başkasına }\end{array}$ \\
\hline Âdem bin Sinan & + & - & - \\
\hline Ahmed Efendi bin Hamid & - & - & + \\
\hline Davud Ağa & + & - & - \\
\hline Emin Ağa bin Seyfullah & + & - & - \\
\hline Hasbi Efendi Bin Nebi Ağa & - & - & + \\
\hline
\end{tabular}

${ }^{36}$ İsmail Kurt, Para Vakıflarn-Nazariyat Ve Tatbikat, s. 124-125; İsmail Kurt, Nazari ve Tatbiki Olarak Para Vakıfları, İstanbul Üniversitesi Sosyal Bilimler Enst., Doktora Tezi, İstanbul 1994, s. 99; VGMA, Defter nr: 991, sayfa: 49; Nazif Öztürk, Mütevelli, DIA, cilt: 32, 2006, s. 217-220; Osman Ergin, Türkiye'de Şehirciliğin Tarihi İnkişafı, s. 72-73; Havva Selcen Yaşar, a.g.t., s. 18; Tahsin Özcan, “Osmanlı Toplumuna Özgü Bir Finansman Modeli: Para Vakıfları, s. 124-128; Tahsin Özcan, "Para Vakıflarıyla İlgili Önemli Bir Belge", s. 107-112; Bahaeddin Yediyıldız, a.g.e., s. 175-185.

${ }^{37}$ VGMA, Defter nr: 989, sayfa: 113. 


\begin{tabular}{|l|l|l|l|}
\hline İlyas Ağa ibni İsmail & + & - & - \\
\hline Recep Ağa bin Ali & + & - & - \\
\hline Rifat bin Bayram & + & - & - \\
\hline Bekir Bin Süleyman & + & - & - \\
\hline Emrullah Ağa İbn Receb & + & - & - \\
\hline Hasan Ağa ibn Süleyman & + & + & - \\
\hline $\begin{array}{l}\text { Kamil bin Zeynel ve Muharrem } \\
\text { bin Arif ve Bilal bin Salih ve } \\
\text { Şaban bin Âdem }\end{array}$ & + & + & - \\
\hline Mustafa bin Kanber & & & \\
\hline Süleyman Bin Faris & + & + & - \\
\hline Yunus Ağa ibn Muslih & + & - & - \\
\hline
\end{tabular}

Yukarıdaki tablodan da anlaşılacağı üzere Kalkandelen'deki bazı para vakıflarında tevliyet erkek evlatlara bir miras olarak bırakılmıştır. İncelenen vakfiyelerde kız çocuklarına böyle bir görev verildiğine rastlanılmamıştır. Bu durumun temelinde Kalakndelen'de ataerkil bir aile yapısına sahip olunması etkili bir faktördür. Yine tevliyetin bu şekilde vakıf kurucusunun evladına, ondan sonra da torunlarına kısaca gelecek nesillerine bir miras gibi bırakılması sahip olunan servetin korunması ve gelecek kuşaklara aktarılması, böylece onlara bir iş imakanı sağlanması amaçlıdır. Bu sayede aile birliğinin sağlanması, ailenin dağılmadan bir arada kalması düşünülmüştür. Görüleceği üzere bu tür vakıflar aile bireyleri arasındaki bağların kuvvetlendirilmesinde ve güçlendirilmesinde etkili olmuştur. ${ }^{38}$

Kalkandelen para vakıfları vakfiyelerindeki şartlara göre çeşitli faaliyetlerde bulunmuşlardır. Bu faaliyetlerin en önde geleni ise ihtiyaç sahiplerine -belirli bir kâr payı karşılığında- herhangi bir kamu desteği olmadan finansman desteği sağlanmasıdır. Vakıfların yaptığı bu hizmet sayesinde devletin sosyal ve ekonomik yapısına son derece olumlu katkılar sağlanmıştır. Bu durumu geçmiş ile mukayese edecek olursak para vakıfları, günümüzdeki ekonomiyi finanse eden faizsiz finans kurumlarının faaliyetlerini etkin bir şekilde gerçekleştirmiştir. Bir anlamda para vakıfları günümüz ekonomik hayatında faaliyet gösteren İslami finans kurumlarının fikri temelini, alt yapısını oluşturmuştur.

\section{Para Vaıflarının İktisadi Hayata Olan Katkıları:}

Kalkandelen para vakıflarının işletilmesinde vakıf faaliyetlerinin sürekliliği ve devamlılığı için reel varlığa dokunulmamasına özen gösterilmiş, paradan sağlanan kârdan/faizden bir miktar pay vakfa verilmiş ve bu meblağ da vakfın çeşitli

38 Şebnem Akipek-Hüseyin Altaş, "Vakıflarda Evladiye Davaları", Ankara Üniversitesi Hukuk Fakültesi Dergisi, cilt: 47, sayı: 1, DOI: 10.1501/Hukfak_0000000647 Yayın Tarihi: 1998, s. 145-151; Hasan Yüksel, "Vakfiyelere Göre Osmanlı Toplumunda Aile", Sosyo Kültürel Değişme Sürecinde Türk Ailesi, c. 2, Ankara 1992, s. 489-492; https://www.tarihtarih.com/?Syf=26\&Syz=382187 Erişim Tarihi:10. 06. 2017 
faaliyetlerinin karşılanmasında kullanılmıştır. Bu sayede hizmet erbabının istihdam edilmesi ve vakıf faaliyetlerinde ortaya çıkabilecek herhangi bir aksamaya neden vermeden vakfın kuruluş amacına uygun bir şekilde uzun yıllar hizmetlerin sürdürülebilmesi amaçlanmıştır. ${ }^{39}$

Aşağıdaki grafikte Kalkandelen'de kurulmuş ve faaliyet göstermiş olan para vakıflarının faiz gelirlerinden elde ettikleri gelirlerin oransal olarak dağılımı gösterilmiştir. Kalkandelen'de bir yılda en fazla faiz gelirleri elde eden vakıf Davud Ağa vakfıdır. Bu vakfın yıllık faiz gelirlerinin genel gelirlere oranı \%21'dir. Süleyman bin Faris vakfı da Kalkandelen para vakıfları faiz gelirlerinin \%20'sine sahiptir. Sadece bu iki vakıf bile genel faiz gelirlerinin neredeyse yarısına sahiptirler. Kalkandelen'de faiz gelirleri açısında en küçük para vakfı ise Emin Ağa bin Seyfullah para vakfıdır. Bu para vakıfının genel vakıflar arasındaki kar oranı \%1'dir.

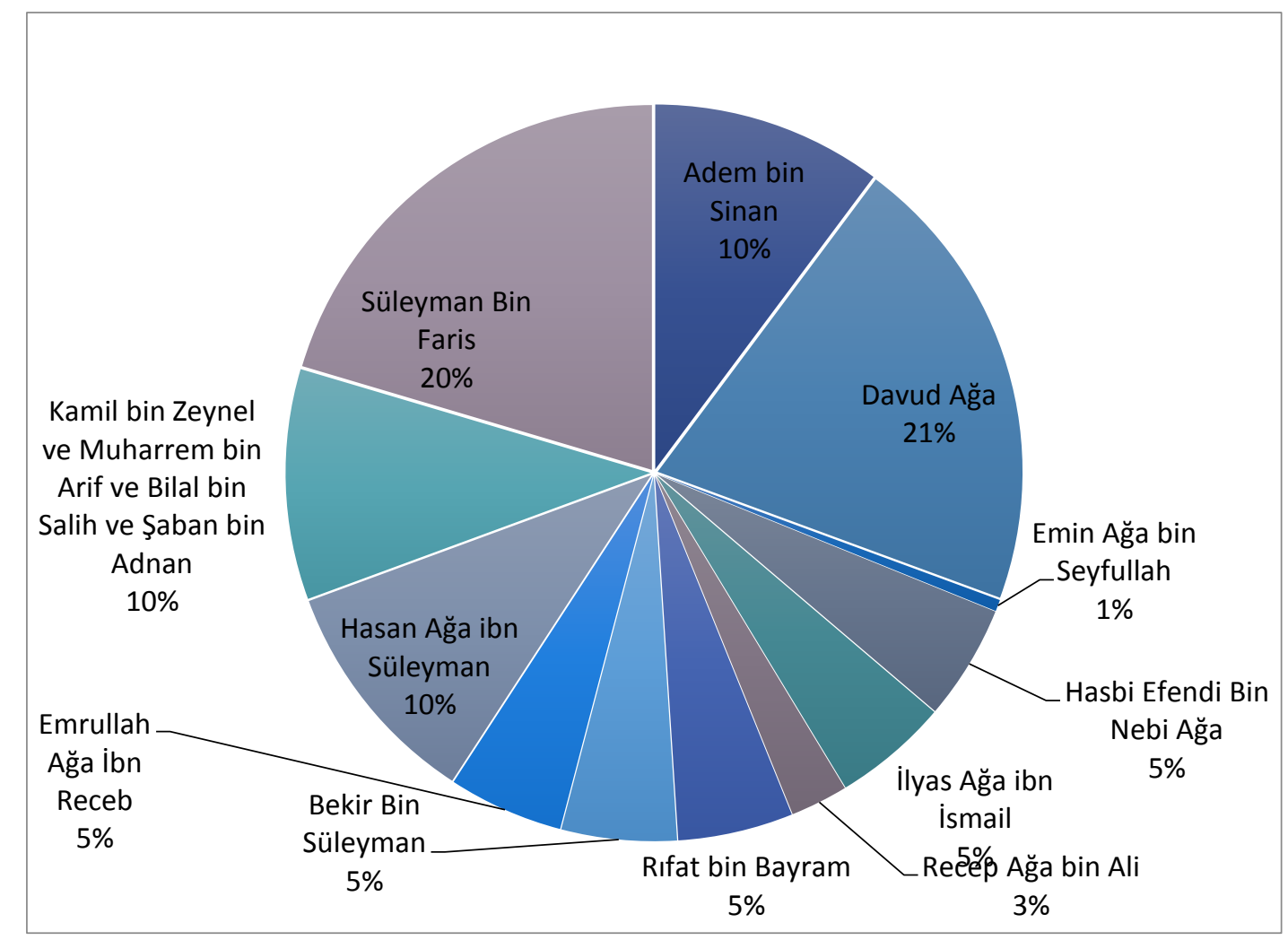

Grafi 2: Kalkandelen Para Vakıflarının Faiz Gelirlerine Göre Büyüklük Oranları

${ }^{39}$ VGMA, Defter nr: 990, sayfa: 2; İrfan Türkoğlu, "Osmanlı Devletinde Para Vakıflarının Gelir Dağılımı Üzerindeki Etkilerı", Süleyman Demirel Üniversitesi Iktisadi ve Idari Bilimler Fakültesi Dergisi yıl: 2013, c. 18, sayı: 2, s. 187-196; ismailkurt.blogcu.com Erişim Tarihi: 10. 06. 2017; İsmail Kurt, a.g.t. s. 140; http://dergi.altinoluk.com/index.php?sayfa=yillar\&MakaleNo=d058s031m1 Erişim Tarihi: 10. 06. 2017; Ömer Lütfi Barkan- Enver Meriçli, "Sosyal ve Ekonomik Yönleriyle Vakıflar", Hüdâvendigâr Livası Tahrir Defteri I, TTK, Ankara 1988; s. I-X; Hamdi Döndüren, Para Vakıfnâmeleri, Altınoluk Dergisi, 1990 Aralık, sayı: 058, sayfa: 31. 
Kalkandelen para vakıflarında, ihtiyaç sahiplerine kredi vermek suretiyle elde edilen kâr/faiz vakfiye şartlarının gerçekleştirilmesinde kullanılırdı. Nakit sermayenin nasıl işletileceği ve ihtiyaç sahiplerine hangi oranlarda kullandırlacağı vakfiyerlde açık

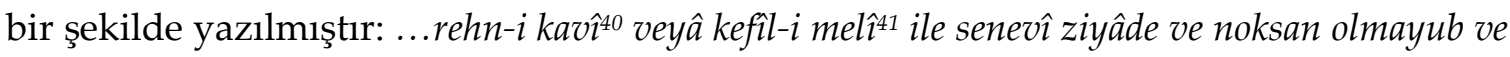
kalemiye nâmiyle bir nesne alunmayub onu on bir buçuk kuruş hesabı üzere istirbâh olunub... Kalkandelen'de vakıfların hepsi varlıklı bir kefil ya da kıymetli bir rehin karşılığında paradan belirli bir kâr oranıyla (genelde \%15) işletilmekteydi. ${ }^{42}$

Kalkandelen para vakıflarının neredeyse tamamı sermayelerini \%15'lik bir kâr payıyla kullandırılması şartı ile vakfedildiği anlaşılmaktadır. Bu vakıfların sermayeleri nakit para olduğundan sadece para vakıflarıdır. Mustafa bin Kanber ve Ahmed Efendi ibn Hamid vakıflarının kâr oranları ise vakfiyelerinde belirtilmemiştir.

Kalkandelen para vakıflarının bir yılda verdikleri kredi miktarı 25.300 kuruştur. Bu kredilerden elde edilen faiz gelirlerinin tutarı ise 2.940 kuruştur. Yukarıdaki grafikten de anlaşılacağı üzere en fazla kâr eden vakıf Davud Ağa ile Süleyman bin Fairs'tir. Bu vakıfların senelik faiz gelirleri 600'er kuruştur. Diğer vakıfların faiz gelirleri ise şöyledir; Âdem bin Sinan 300, Emin Ağa bin Seyfullah 15, Hasbi Efendi Bin Nebi Ağa 150, İlyas Ağa ibn İsmail 150, Recep A $\breve{g} a$ bin Ali 75, Rıfat bin Bayram 150, Bekir Bin Süleyman 150, Emrullah Ağa İbn Receb 150, Hasan Ağa ibn Süleyman 300, Kamil bin Zeynel ve Muharrem bin Arif ve Bilal bin Salih ve Şaban bin Adnan 300 kuruştur.

Vakıflar Genel Müdürlüğü Arşivinde 989 numaralı defterin 227. sayfasında kayıtlı olan Kalkandelen'in en büyük para vakıflarından biri olan Davud Ağa Vakfına aittir. Davud Ağa para vakfının vakfiyesinde zikredildiği üzere vakfedilen 4.000 kuruş mütevelli tarafından, ...dört bin guruşu bâ-yed-i mütevellî alâ-vechi'l-helâl rehn-i kavî veya kefill-i melî ile senevî ziyâde ve noksân olmayub ve kalemiyye nâmıla bir nesne alunmayub onu

${ }^{40}$ Kıymeti borç miktarı veya daha az olan ve medyunun temerrüdü halinde kıymeti borcu ifaya kâfi olan rehindir. İster menkul isterse gayr-i menkul olsun: http://www.vgm.gov.tr/sayfa.aspx?Id=30\#P Erişim Tarihi: 10. 06. 2017

${ }^{41}$ Servet sahibi kefil demektir: http://www.vgm.gov.tr/sayfa.aspx?Id=30\#P Erişim Tarihi: 10. 06. 2017

42İsmail Kurt, a.g.t., s. 84, 104: Tahsin Özcan, “Osmanlı Toplumuna Özgü Bir Finansman Modeli.., s. 127; Adnan Ertem, Bir Medeniyetin İzdüşümü Vakıflar, Vakıflar Genel Müdürlüğü Yay., İstanbul 2012, s. 182; Ahmed Akgündüz, İslâm Hukukunda ve Osmanlı Tatbikatında Vakıf Müessesesi, Osmanlı Araştırmaları Vakfı Yay., İstanbul, 1996, s. 220-230; VGMA nr: 990, sayfa: 52; http://dergi.altinoluk.com/index.php?sayfa=yillar\&MakaleNo=d053s017m1 Erişim Tarihi: 10. 06. 2017; Bahaeddin, Yediyıldız, "18. Asır Türk Vakıflarının İktisadî Boyutu", Vakıflar Dergisi, sayı: 18, Ankara 1984, s. 5-41; Hami Döndüren, “Osmanlı Tarihinde Bazı Faizsiz Kredi Uygulamalarıve Modern Türkiye'de Faizsiz BankacılıkTecrübesi", Uludağ Üniversitesiilâhiyat Fakültesi Dergisì, cilt: 17, sayı: 1, 2008, s. 1-24; Ayrıca bkz; Ali Himmet Berki, Açıklamalı Mecelle, Hikmet Yayınları, İstanbul 1990; Mehmet Bulut Ve Cem Korkut, "Finansal İstikrar Ve Para Vakıfları Etkisi: Rumeli Para Vakıfları Örnekleri", Journal of Islamic Economics and Finance - İslam Ekonomisi ve Finansı Dergisi, Vol. 2, No. 1 (1 June 2016): pp. 55-76; Halime Önk, a.g.t., s. 17; Cantürk Kayahan -İrfan Görkaş, Osmanlı Dönemi Bölgesel Kalkınmanın Finansman Aracı Olarak Para Vakıflarının Kullanımı, Muhasebe Ve Finansman Dergisi, sayı: 44, İstanbul 2009, s. 212-227; Tahsin Özcan, Osmanlı Para Vakıfları, Kanuni Dönemi Üsküdar Örneği, s. 50-55. 
on bir buçuk hesâbı üzre istirbah olunub...., bu işlem esnasında da varlıklı bir kefil ya da kıymetli bir rehin alınacaktır. Bu durumda vakfedilen para 4.000 kuruş olduğuna göre onu on bir buçuk hesabıyla istirbah edileceğine göre bu paranın aylık gelirini bulmamız gerekmektedir. 4.000 kuruş \%15 kuruştan istirbah edildiğinde 600 kuruş edeceğine göre, asl-1 mal ve faiz gelirlerinin toplamı 4.600 kuruş olacaktır. Davud Ağa vakfiyesinde vakfedilen paradan elde edilen kârdan yıllık belirli bir miktarı caminin tamirine, camide hitabet vazifesini ifa eden görevliye, fakir ve fukaraya dağıtılmasını açık bir şekilde ifade edilmiştir. ${ }^{43}$

Başka bir vakfiyede de benzer bir durum söz konusudur. Kosova Vilâyeti dâhilinde Prizren Sancağı'na mülhak Kalkandelen Kazasına tabi Germul köyü ahalisinden hayırsever Mustafa bin Kanber 2.500 kuruşunu vakfetmiş ve parasının nasıl işletilmesi gerektiğini de vakfiyesinde belirlemiştir. Bu vakıfta vakfedilen miktar 2.500 kuruştur. Yine diğer vakıflarda da olduğu üzere onu on bir buçuk hesabı üzere istirbah edilecektir. 2.500 kuruş \%15 oranında istirbah edildiğinde 375 kuruş etmektedir. Asl-1 mal ve faiz gelirleri toplamı 2.875 kuruş etmektedir. Hayırsever Mustafa ibn Kanber güvenilir bir kefil ya da kıymetli bir rehin karşılı̆̆ında bu işlemin yapılmasını şart koşmuştur. Yukarıdaki örnekte olduğu gibi varlıklı bir kefil ya da kıymetli bir rehin karşılığında verilmesine izin verilmiştir. Buradan elde edilen gelirin de Germul'daki camiide görev yapan hatibe verilmesini şart koşulmuştur. ${ }^{44}$

Kalkakndelen para vakıflarının faaliyet alanları arasında cami ya da mescitlerde görevli olan imam ve hatiplerin ihtiyaçlarının giderilmesi, cami veya mescitlerin bakım ve onarımlarının yapılması, vakfın kurulduğu yerdeki eğitim-öğretim faaliyetlerinin desteklenmesi ve fakir ve fukaraların ihtiyaçlarının giderilmesi için çaba sarf edilmesi olarak sıralanabilir. Bu sayede devlet eliyle sosyal hizmet ve yardımlara yapılan harcamaların azaltılması gibi son derece önemli faydaları olmuştur.

Aşağıdaki tabloda Kalkandelen para vakıflarının bir yıllık faiz gelirlerinden elde ettikleri kârların kullanım alanları ayrıntılı olarak gösterilmiştir. Genel olarak bakıldığında bu vakıflar imam ve hatiplerin desteklenmesine çalışmıştır. Bu da yerel halkın dini hayata olan gereksinimlerinin ön planda olduğu fikrini uyandırmaktadır. Para vakıflarının eğitim öğretim faaliyetlerine olan destekler ise sınırlı sayıda olmuştur. Kalkadelen'deki para vakıflarından sadece Ahmed Efendi bin Hamid para vakfı eğitim ve öğretimi desteklemek için gelirlerinden bir miktar para ayırmıştır.

Kalakndelen'deki para vakıflarının faaliyet alanlarına bakıldığında Davud Ağa para vakıf imam ve hatiplerin maaşlarının karşılanması, ibadethanelerin çeşitli ihtiyaçlarının giderilmesi ve fakir ve fukaraya yaptığı yardım faaliyetlerine bakıldığından Kalkandelen'deki en faal para vakıftır.

\footnotetext{
${ }^{43}$ İsmail Kurt, a.g.t., s. 104; VGMA, Defter nr: 989, sayfa: 227.
}

${ }^{44}$ VGMA, Defter nr: 989, sayfa: 193; İsmail Kurt, a.g.t., s. 104. 
Tablo 3: Kalkandelen Para Vakıflarının Yardım Faaliyetleri

\begin{tabular}{|l|l|l|l|l|}
\hline & $\begin{array}{l}\text { İmam ve } \\
\text { Hatiplere }\end{array}$ & $\begin{array}{l}\text { Cami ve } \\
\text { Mescitlere }\end{array}$ & $\begin{array}{l}\text { Eğitim- } \\
\text { Ögretime }\end{array}$ & $\begin{array}{l}\text { Fakir } \\
\text { Fukaraya }\end{array}$ \\
\hline Âdem bin Sinan & + & - & - & + \\
\hline Ahmed Efendi bin Hamid & - & - & + & - \\
\hline Davud Ağa & + & + & - & + \\
\hline Emin Ağa bin Seyfullah & + & - & - & + \\
\hline Hasbi Efendi Bin Nebi Ağa & + & - & - & - \\
\hline İlyas Ağa ibni İsmail & + & - & - & + \\
\hline Recep Ağa bin Ali & + & - & - & - \\
\hline Rufat bin Bayram & + & - & - & + \\
\hline Bekir Bin Süleyman & + & - & - & - \\
\hline Emrullah Ağa İbn Receb & + & - & - & + \\
\hline Hasan A ğa ibn Süleyman & + & - & - & - \\
\hline $\begin{array}{l}\text { Kâmil bin Zeynel ve Muharrem } \\
\text { bin Arif ve Bilal bin Salih ve } \\
\text { Şaban bin Âdem }\end{array}$ & + & + & - & - \\
\hline Mustafa bin Kanber & & & & \\
\hline Süleyman Bin Faris & + & - & - & - \\
\hline Yunus Ağa ibn Muslih & + & - & - & + \\
\hline
\end{tabular}

\section{Para Vakıflarından Cami, İmam ve Hatiplerine Yapılan Destekler:}

Kalkandelen para vakıflarının hemen hemen hepsi kurulmuş oldukları yerde görev yapan imam ve hatipler gibi din görevlilerine destek olmuş, onlar için vakıflardan belirli bir miktar para ayrılmıştır. Bu sayede vakıflar ahalinin dini ihtiyaçlarının giderilmesinde önemli katkılar sağlamıştır.

Adem bin Sinan vakfı Sedlerce-i Bala'da görev yapan imam senelik 300 kuruş̧, Hasbi Efendi bin Nebi Ağa vakfi Kalkandelen merkezinde yer alan Solcu Bey mahallesindeki Sinani Zaviyesi'ndeki camide görev yapacak olan hatibe senelik 150 kuruş ${ }^{46}$, İlyas Ağa ibn İsmail Vakıf Sedlerce-i Bala'da görev yapan imam efendiye 150 kuruş ${ }^{47}$, Receb Ağa bin Ali Vakfı Beştime-I Bala köyünde köylüler tarafından bina ve inşa edilmiş olan camide imamet ve hitabet vazifesini yerine getiren kişiye senelik 75 kuruş $^{48}$, Rıfat bin Bayram Vakfı kurulduğu yer olan Kalkandelen'e bağlı Brodeç köyündeki camide hitabet vazifesini yerine getirmekte olan kimseye senelik 150 kuruş ${ }^{49}$, Bekir bin Süleyman Vakfı Gostivar nahiyesine bağlı Baralişte köyündeki camide görev

\footnotetext{
45 VGMA, Defter nr: 991, sayfa: 31.

46 VGMA, Defter nr: 990, sayfa: 81.

${ }^{47}$ VGMA, Defter nr: 989, sayfa: 226.

48 VGMA, Defter nr: 990, sayfa: 31.

${ }^{49}$ VGMA, Defter nr: 990, sayfa: 73.
} 
yapan hatibe senelik 150 kuruş50, Süleyman bin Fairs'de Vibçe köüyündeki camide görev yapan imama senelik 150 kuruş verilmesi şart koşmuştur. ${ }^{51}$

Genel olarak bakıldığından para vakıflarından Kalkandelen'deki camilerde görev yapan imamlara günlük ortalama 1 kuruşun çok altında bir ücret verilmekteydi. Mesela bu dönemde Trabzon'daki para vakıflarından imamlara günlük 1'er kuruş maaş verildiği göz önünde tutulursa Kalkandelen'deki imam ve hatiplerin ekonomik yetersizlikler altında görevlerini yerine getirdiği anlaşılmaktadır. ${ }^{52}$

Kalkandelen'deki para vakıfları imam ve hatiplerin maaşlarının karşılanmasının yanı sıra halkın ibadetlerini rahat bir şekilde yerine getirmeleri için cami ve mescitlerin çeşitli ihtiyaçlarının giderilmesine ve buraların tamir edilmesine özen gösterilmiştir. $\mathrm{Bu}$ gibi ihtiyaçların karşılanması için hayırseverler vakıflarından belirli bir miktar para da ayırmışlardır. Kalkadelen'in en büyük para vakıflarından biri olan Davud Ağa vakfı Nebruşten köyündeki caminin tamiri için senelik 150 kuruş ayırmaktaydı. Ayrıca bu camide görev yapan hatibe de günlük 1,36 kuruş senelik ise 500 kuruş maaş verilmekteydi. ${ }^{53}$

Kalkandelen'e bağlı Gavrance köyünde Kamil bin Zeynel ve Muharrem bin Arif ve Bilal bin Salih ve Şaban bin Adnan iki bin kuruş sermaya ile para vakıf kurmuşlardır. Vakfiyesine göre vakfın senelik faiz gelirlerinden hasıl olan 300 kuruşun yarısını aynı köyde inşa ve bina ettikleri camide görev yapan imam efendiye verilmesini, kalan diğer yarısının da ...kanadillere sarf ve kanadil-i mezkûreye îkâd idene verile ... denilerek caminin kandillerinin masraflarının karşılanmasında ve bunun için görevli kişiye verilmesini şart koşmuşlardır. ${ }^{54}$

\section{Para Vakıflarının Eğitim ve Öğretim Faaliyetlerine Yapılan Destekler:}

Kalkandelen para vakıfları eğitim ve öğretimi desteklenmekte, bu tür müsseselerde görev yapan müderrisler için vakıflarından bir pay ayrılmaktaydı. Örneğin Kalkandelen merkezinde Köprü mahallesinde ikamet eden hayırsever Ahmed Efendi bin Hamid 500 kuruşunu vakfetmiştir. Bu sermayeyi de belirli bir kâr/faiz oranıla ile işletilmesini vakfiyesinde şart koşmuştur. Vakfın mütevelliliğine de ...bĥa-yed-i mütevellî rehn-i kavî ve yâhud kefill-i melî ile âhara irbâh olunub senevî rıbhı Çarşı Bâlâ Medresesi müderrisi bulunan işbu hâzır bi'l-meclis Abdullah Efendi'ye mâdâme'l-hayât meşrûta ola ve mûmâ-ileyh vefât iddükden sonra medrese-i mezkûrede müderrislik vazîfesini îfâ idecek olan zâta meşrûta ve meblă̆g-ı mezkûf-ı mezkûrun tevliyeti mâdâme'l-hayât müderrisi mûmâ-ileyh Abdullah Efendi'ye meşrûta ola ve ba'de'l-vefât tevliyet-i mezkûre medrese-i mezkûrede müderris olacak zâta meşrûta ola... ifadesiyle yaşamı boyunca Çarşı Bala Medresesi müderrisi olan Abdullah Efendi'ye, o vefat ettikten sonra yine aynı medresede müderris olan kişiye verilmesini şart koşmuştur. ${ }^{55}$

\footnotetext{
50 VGMA, Defter nr: 990, sayfa: 52.

51 VGMA, Defter nr: 990, sayfa: 91.

52 Şehabettin Usta, a.g.m., s. 66-67.

${ }^{53}$ VGMA, Defter nr: 989, sayfa: 227.

${ }^{54}$ VGMA, Defter nr: 988, sayfa: 278.

55 VGMA, Defter nr: 990, sayfa: 43.
} 


\section{Para Vakıflarından Yapılan Sosyal Yardımlar:}

Kalkandelen para vakıflarının hemen hemen hepsi fakir ve fukaraların ihtiyaçlarının karşılanması için belli bir meblağ ayırmışlardır. Örneğin Vakıflar Genel Müdürlüğü arşivinde 991 nolu defterin 40. sayfasında kayıtlı olan Kalkandelen'e bağlı Gositivar nahiyesindeki Emrullah Ağa İbn Receb Vakfına ait - Bu vakıf 5 Şubat 1908 tarihinde tasdik edilmiştir- vakfiyede zikredildiği üzere hayırsever tarafından vakfedilen bin kurus,un terikeden ifraz edildiği, mütevelli eliyle bu meblâğın istirbah olunmasının şart koşulduğu, nemasının ise nerelere sarf edilmesi gerektiği şu şekilde belirtilmiştir: ...Ve murûr-ı eyyâm ve kurûr-ı a'vâm ile şerâit-i mezkûrenin icrası müte'azzir olur ise rıbh-ı mezkûr mutlaka fukarâ-i müslimine virile... ${ }^{56}$

Hayırseverler vakfiyelerinde nerelere ne şekilde harcamalar yapılacağını, vefatlarından sonra kendileri veyahut yakınları için hayr $u$ hasenatın yapılmasını $d a$ vasiyet etmişlerdir. Bu vasiyetlerinin uygulanabilmesi için de vakıf gelirlerinin bir kısmı bunlar için ayrılmıştır. Vakıflar Genel Müdürlüğü Arşivinde 990 nolu defter, 85. Sayfasında kayıtlı vakfiyede her sene vakıf kurucusu adına ve vefat etmiş olan eşi için birer adet koyun kurban edilmesini vasiyet etmiştir. ${ }^{57}$

\section{SONUÇ}

Kalkandelen para vakıfları genel olarak 19. yy sonu ile 20. yy başlarında faaliyet göstermiştir. Bu dönem özellikle Makedonya sorunun iyiden iyiye devleti siyasi, hukuki ve ekonomik anlamda meşgul ettiği bir buhranlar dönemidir. Osmanlı Devleti bu siyasi çalkantı ve ekonomik kriz döneminde Müslüman ahalinin desteklenmesi için Ziraat Bankası aracılığıyla krediler verilmiştir. Devlet vermiş olduğu bu maddi destek ile bölgedeki Müslüman/Türk varlığının devam ettirilmesine gayret sarf etmiştir. İşte tam da bu zamanda para vakıfları ihtiyaç sahiplerine verdikleri maddi desteklerle bölgede gittikçe daha zor günler geçirmekte olan Müslüman/Türk unsurlarının sosyal ve ekonomik hayatta daha fazla ve daha etkin bir rol üstlenmelerinde katkı sağlamıştır.

Para vakıflarının dini ve ilmi müesselere yapmış oldukları maddi destek ve katkılar ile bölgedeki soydaş ve dindaşlarımızın kültürel bir dejenerasyona uğramasının önüne geçilmesinde faydalar sağlamıştır. Bunların yanında para vakıflarının cami, mescit, medrese gibi İslami ve ilmi müesseselere yapmış oldukları maddi ve manevi destekle bu tür dini ve kültürel mirasların günümüzde dek ayakta kalmasına yardımcı olmuştur.

\footnotetext{
${ }^{56}$ VGMA, Defter nr: 991, sayfa: 40; İsmail Kurt, Para Vakıfları-Nazariyat Ve Tatbikat, s. 121.

57 VGMA, Defter nr: 990, sayfa: 85; İsmail Kurt, a.g.t., s. 15; Kalkandelen'deki vakfiyeleri incelediğimizde genel olarak paranın haricinde gayr-i mülk varlıkların da vakfedildiğine ve bu varlıkların belirli bir bedel karşılığında kiraya verildiğine şahit olmaktayız. Bu sayede gayri mülkten elde edilen kira gelirleri vakfın yerine getirdiğ hizmetler için harcanmıs,ır. Bununla birlikte vakfa bağışlanan nakit ya da gayr-i menkuller vakfın amaçları doğrultusundan kullanılması şart koşulmaktaydı. Örneğin Hacı Mustafa Ağa Kalkandelen kazası Gostivar köyünde inşa ve bina eylediği cami ve medreseye Lüleburgaz'daki çiftliğini vakfetmiş ve buradan elde edilecek olan gelirlerin vakıf şartlarına göre kullanılmasını vakfiyesinde ifade etmiştir. Ayrıca Vüzeradan Mustafa Paşa Kalkandelen kazasında iki köyü ve mezralarını vakfetmiştir: BOA A.DVN, nr. 158/89; BOA, TS.MA.d, nr. 7024; İrfan Türkoğlu, a.g.m., s. 192-193.
} 
Böylece Rumeli'deki Müslüman Türk sosyal kimliğinin, kültürünün günümüze kadar ulaşmasında, gelecek nesillere aktarılmasında önemli bir rol üstlenmiştir.

Kalkandelen para vakıflarının fakir fukaraya yapmış oldukları yardım faaliyetleri ile de Müslüman/Türk unsurların dayanışma içerisinde olmasına son derece önemli katkılar sağlanmış, sosyal yardımlaşma teşvik edilmiştir. Ayrıca para vakıfları her geçen gün derinleşen siyasal krizrelerin ve duygusal kopuşların yaşandığı, terör örgütlerinin faaliyetlerini arttırdığı, savaş tamtamlarının şiddetli bir şekilde çalıdığı Makedonya'da yapmış oldukları sosyal ve ekonomik yardımlar ve faaliyeterle toplumsal barışın sağlanmasında büyük bir firsat olmuştur.

Son söz olarak bu tür hayır kurumları Makedonya'da Müslüman/Türk sosyal ve kültürel dokusunun sağlamlaşmasında etkili olunmuştur. Genelde vakıfların özelde ise para vakıflarının bu faaliyetlerinin kıymeti Osmanlı Devleti'nin bu toprakları terk etmesinden sonra net olarak anlaşılmıştır. Nitekim yaşanan savaşlarla siyasi olarak bir birimizden fiziksel olarak koparılmış olsak da anavatan ile evlad-1 fatihan arasındaki duygusal bağlar kopmamış, hala devam edegelmiştir. Para vakıfları Makedonya'da Müslüman/Türk unsuru varlığının, sosyal kimliğinin günümüze de kadar ayakta kalmasını sağlayan etkenlerden sadece biridir.

\section{KAYNAKÇA}

\section{VAKIFLAR GENEL MÜDÜRLÜĞÜ ARŞIVİ}

VGMA, Defter nr: 991, sayfa: 49; Defter nr: 989, sayfa: 113; Defter nr: 991, sayfa: 49; Defter nr: 990, sayfa 91; Defter nr: 989, sayfa 113; Defter nr: 989,sayfa 70; Defter nr: 990, sayfa 2; Defter nr: 991, sayfa: 40; Defter nr: 990, sayfa: 85; Defter nr: 990, sayfa: 52; Defter nr: 989, sayfa: 189; Defter nr: 989, sayfa: 193; Defter nr: 988, sayfa: 278279; Defter nr: 991, sayfa: 31; Defter nr: 990, sayfa: 43; Defter nr: 989, sayfa: 227; Defter nr: 990, sayfa: 156; Defter nr: 990, sayfa 95; Defter nr: 989, sayfa: 226; Defter nr: 990, sayfa: 31; Defter nr: 990, sayfa: 73.

\section{BAŞBAKANLIK OSMANLI ARŞİII}

A.DVN, nr. 158/89; BOA, TS.MA.d, nr. 7024

\section{KITAP VE MAKALELER}

AKGÜNDÜZ, Ahmed, İslâm Hukukunda ve Osmanlı Tatbikatında Vakıf Müessesesi, Osmanlı Araştırmaları Vakfı Yay., İstanbul, 1996.

AKİPEK Şebnem - ALTAŞ, Hüseyin, "Vakıflarda Evladiye Davaları”, Ankara Üniversitesi Hukuk Fakültesi Dergisi, cilt: 47, sayı: 1 DOI: 10.1501/Hukfak_0000000647 Yayın Tarihi: 1998, s.145-151.

ALKAN, Mustafa, Adana Para Vakıfları İnsan, Vakıf ve Şehir, TTK, Ankara 2014.

ARMAĞAN, Mustafa, "Osmanlı, Bir Vakıf Medeniyeti”, Sivil Toplum Düşünce ve Araştırma Dergisi, sayı: 15, İstanbul 2006, s. 169-171.

ARUÇİ, Muhammed, "Kalkandelen", DİA, cilt: 24, Ankara 2001, s. 262-263.

ASLAN, Nasi, "Osmanlı Toplumunda Para Vakıflarının Kurumsallaşmasında Rol Oynayan Faktörler", Din̂̂ Araştırmalar, Eylül-Aralık c. I, c. 2, Ankara 1998. 
AŞAR, Betül, İslam Hukuk Tarihinde Para Vakıfları Ve Finansman Kaynağı Olarak Kullanılması, Ondokuzmayıs Üniversitesi Sosyal Bilimler Enstitüsü, Yüksek Lisans Tezi, Samsun 2011.

AYDIN, H. Veli, "Selanik'te 18. Yüzyılın İlk Yarısında Para Vakıfları Ve Kredi İşlemleri", Tarih Incelemeleri Dergisi, XXIX / 1, 2014, s. 87-106.

BARKAN, Ömer Lütfi - Meriçli, Enver, "Sosyal ve Ekonomik Yönleriyle Vakıflar", Hüdâvendigâr Livası Tahrir Defteri I, TTK, Ankara 1988, s. I-X.

BAYYİĞİT, Mehmet, "Sosyal Yardımlasma Ve Dayanısma Kurumu Olarak Vakıflar", Selçuk Üniversitesi İlâhiyat Fakültesi Dergisi, Bahar, sayı: 11, Konya, 2001, s. 59-67.

BERKI, Ali Himmet, Vakfa Dair Yazılan Eserlerle Vakfiye Ve Benzeri Vesikalarda Geçen Istılah Ve Tâbirler, Vakıflar Gen. Müd. Neş., Ankara 1966.

"Vakıfların Tarihi, Mahiyeti, İnkişafı ve Tekâmülü, Cemiyet ve Fertlere Sağladığı Faideleri", Vakıflar Dergisi, sayı: 6, İstanbul 1965, s. 915.

“'Vakıfların Hukuk ve Tarih Bakımından Kıymeti", Vakıflar Dergisi, say1: 6, İstanbul 1965, s. 5-9. Açıklamalı Mecelle, Hikmet Yayınları, İstanbul 1990.

BULUT, Mehmet, - Korkut, Cem, “Finansal İstikrar Ve Para Vakıfları Etkisi: Rumeli Para Vakıfları Örnekleri", Journal of Islamic Economics and Finance - İslam Ekonomisi ve Finansı Dergisi, Vol. 2, No. 1 (1 June 2016): pp. 55-76.

"Finansal İstikrar Ve Para Vakıfları Etkisi: Rumeli Para Vakıfları Örnekleri", MPRA Paper No. 73902, posted 24 September 2016 19:05 UTC.

ÇAM, Mevlüt, 16. yüzyıl Osmanlı Dönemi Arapça vakfiyeler ve Osmanlı sisteminde eğitim (Saraybosna Hüsrev Bey ve Edirne Sultan II. Selim medreseleri örneğinde), Gazi Üniversitesi Eğitim Bilimleri Enstitüsü, Yüksek Lisans Tezi, Ankara 2016.

ÇİFTÇİ, Cafer, "18.yy da Bursa'da Para Vakıfları ve Kredi İşlemleri”, Ankara Üniversitesi Dil ve Tarih-Coğrafya Fakültesi Tarih Bölümü Tarih Arastırmaları Dergisi, c. 23., sayı: 36, Ankara 2004, s. 79-102.

ÇÖTELİ, Methiye Gül, " İslam Kentinde Vakıfların Ticaret Bölgesinin Oluşumu Üzerine Etkisi: Hayrat-Akar İlişkisinin Döngüsel Doğası", Vakıflar Dergisi, sayı: 45 - Haziran 2016, s. 9-28.

DEDE, Mevlüt, Üsküp Vakıflart-Bir Sosyal Tarih İncelemesi- Gazi Üniversitesi Sosyal Bilimler Enstitüsü, Doktora Tezi, Ankara 2015.

DEĞER, Alper - CANAN, Erdoğan "16. Ve 18 Yy Arasında Bursa Para Vakıfları Ve Bursa Ekonomisine Etkileri", Uludağ Üniversitesilktisadi ve İdari Bilimler Fakültesi Dergisi, Cilt XXVIII, say1: 1, 2009, s. 85-99.

DEMİREL, Ömer, Sivas Şehir Hayatında Vakıfların Rolü, TTK, Ankara 2000.

DÖNDÜREN, Hami, “Osmanlı Tarihinde Bazı Faizsiz Kredi Uygulamaları ve Modern Türkiye' de Faizsiz BankacılıkTecrübesi”, Uludă̆ Üniversitesi İlâhiyat Fakültesi Dergisi, cilt: 17, sayı: 1, 2008, s. 1-24.

DURMUŞ, Muhammed Emin, Muhasebe Kayıtları Işı̆̆ında 18. Yü̈yılın Son C,eyreğinde Ǚkü̈dar Para Vakıfları, Sakarya Üniversitesi Sosyal Bilimler Enstitüsü, Yüksek Lisans Tezi, Sakarya 2016.

EKİNCI, Sema Nur, Osmanl Şehrinin Oluşumunda Vakfiyelerin Rolü, Marmara Üniversitesi Sosyal Bilimler Enstitüsü, Yüksek Lisans Tezi, İstanbul 2016. 
ELITOK, Hüseyin, Vakıflar Genel Müdürlü̆̈̈̈ Arşivinde Bulunan Hanım Sultanlara Ve Padişahlara Ait Bir Grup Vakfiyenin Hat, Tezhip Ve Cilt Bakımından İncelenmesi, Atatürk Üniversitesi Sosyal Bilimler Enstitüsü, Doktora Tezi, Erzurum 2014.

ERGIN, Osman, Türkiye'de Şehirciliğin Tarihi İnkişafı, İstanbul Üniversitesi Hukuk Fakültesi İktisat ve İ́timaiyat Enstitüsü Neşriyatı, İstanbul 1935.

ERTEM, Adnan, Bir Medeniyetin İzdüşümü Vakıflar, Vakıflar Genel Müdürlüğü Yay., İstanbul 2012.

FURAT, Ahmet Hamdi, "İslam Hukukunda Vakıf Akdinin Bağlayıcılığı", İstanbul Üniversitesi Ilahiyat Fakültesi Dergisi, 2012, Vol. 27, s. 61-84. 24p.

GÜNAY, Mehmet Hac1, "Vakıf", DİA, cilt: 42, İstanbul 2012, s. 475-479.

GÜRAN, Tevfik, Ekonomik ve Mali Yönleriyle Vakıflar: Süleymeniye ve Şehzade Süleyman Paşa Vakıfları, Kitabevi, İstanbul 2006.

GÜRSOY, Çiğdem, Şeyhü'l-İslâm Ömer Hüsameddin Ve Kazasker Mehmed Vahid Efendilerin Para Vakıflarına Dair Meşihat Arşivindeki 1698 Numaralı Defterin Dĕ̆erlendirilmesi, İstanbul Üniversitesi Sosyal Bilimler Enst., Yüksek Lisans Tezi, İstanbul 2011.

İBRAHIMGİL, Mehmed, 1997, "Kalkandelen (Tetovo) Alaca-Paşa Camii", Vakıflar Dergisi, XXVI, s. 249-66.

KARAMAN, Hayrettin, Anahatlarıla İslam Hukuku-2, Ensar Neşriyat, İstanbul 2016.

KAYAHAN, C. - GÖRKAŞ İ., "Osmanlı Dönemi Bölgesel Kalkınmanın Finansman Aracı Olarak Para Vakıflarının Kullanımı", Muhasebe Ve Finansman Dergisi, s: 44, İstanbul 2009, s. 212-227.

KAZICI, Ziya, Osmanlı'da Vakıf Medeniyeti, Kayıhan Yayınları, İstanbul 2003.

KELEŞ, Hamza, “Osmanlılarda 19. Yüzyıldaki Para Vakıflarının İşleyiş Tarzı ve İktisadî Sonuçları Üzerine Bir Çalışma -Karacabey (Mihaliç) Kazası Örneği", G.Ü. Gazi Ĕ̆itim Fakültesi Dergisi, Cilt 21, Sayı: 1, 2001, s. 189-207.

KURT, İsmail, "İstanbul Para Vakıfları", Türk Dünyası Arastırmaları Dergisi, sayı:101, İstanbul 1996.

Araştirma Vakfi, İstanbul 2006.

Nazari ve Tatbiki Olarak Para Vakıfları, İstanbul Üniversitesi Sosyal Bilimler Enst., Doktora Tezi, İstanbul 1994.

KOZAK, İbrahim Erol, Bir Sosyal Siyaset Müessesesi Olarak Vakıf, Akabe yayınları, İstanbul 1985.

OKUR, Kaşif Hamdi, "Para Vakıfları Bağlamında Osmanlı Hukuk Düzeni ve Ebussuud Efendinin Hukuk Anlayışı Üzerine Bazı Değerlendirmeler", Gazi Üniversitesi Çorum İlahiyat Fakültesi Dergisi, 2005/1-2, cilt: IV, say1: 7-8, ss. 33-58.

OMEROV, Mumın, Vakfiyelere göre XV-XVIII. asırlarda Makedonya'da vakıflar ve işlevleri, Uludağ Üniversitesi Sosyal Bilimler Enstitüsü, Yüksek Lisans Tezi, Bursa 2016.

ÖNK, Halime, Osmanlı Dönemi Para Vakıflarıyla Günümüz Katılım Bankalarının Karşılaştırılması, Afyonkarahisar Üniversitesi Sosyal Bilimler Enst., Yüksek Lisans Tezi, Afyonkarahisar 2015.

ÖZGÜDENLİ, Osman Gazi, “Vakfiye”, DİA, İstanbul 2012, cilt: 42, s. 465-467.

ÖZCAN, Tahsin, "Osmanlı Toplumuna Özgü Bir Finansman Modeli: Para Vakıfları”, Çerçeve, Yıl: 16, Sayı: 48, (Ekim 2008), s. 124-128. 
"Para Vakıflarıla İlgili Önemli Bir Belge", İlam Araştırma Dergisi, III/2 (Temmuz-Aralık 1998), s. 107-112.

" İbn Kemal'in Para Vakıflarına Dair Risâlesi", İslâm Araştırmaları Dergisi, sayı: 4, İstanbul 2000, s. 31-41.

"Sofyalı Bâlî Efendi'nin Para Vakıflarıyla İlgili Mektupları", İslâm Araştırmaları Dergisi, İstanbul 1999, s. 125-155.

Osmanlı Para Vakıfları, Kanuni Dönemi Üsküdar Örneği, TTK, Ankara 2003.

Vakıf Medeniyeti ve Para Vakıfları, Türkiye Finans Kültür Yayınları, İstanbul 2010.

ÖZKAN, Selim Hilmi, "Bir Muhalefet Olarak İmam Birgivi ve Sosyal Hayata Etkileri", Uluslararası Balıkesir'e Değer Katan Şahsiyetler Sempozyumu Bildirileri, Karesi Belediyesi Kültür Yayınları, Balıkesir, 2014, s. 381-387.

"Bir ilim ve Kültür Şehri: Sofya", Balkanlar'da Osmanlı Mirası ve Defter-i Hakani, C. I, Libra Yayınları, İstanbul, 2015, s. 378-393.

ÖZSARAÇ, Yakup, Para Vakıfları Ve Risk Sermayesi Örnek Olay (Vakıf Risk Sermayesi A.Ş), Gazi Üniversitesi Eğitim Bilimleri Enstitüsü, Yüksek Lisans Tezi, Ankara 2008.

ÖZTÜRK, Nazif, Elmalılı M. Hamdi Yazır Gözüyle Vakıflar: Ahkâmu'l-Evkaf, Türkiye Diyanet Vakfı, Ankara 1995.

Menşe'i ve Tarihi Gelişimi Açısından Vakıflar, Vakıflar Müdürlüğü Yayınları, Ankara 1983.

Türk Yenileşme Tarihi Çerçevesinde Vakıf Müessesesi, Türkiye Diyanet Vakfı Yayınları, Ankara 1995.

"Sosyal Siyaset Açısından Cumhuriyet Öncesi Vakıfları", Cumhuriyetin 80.Yılında Uluslararası Vakıf Sempozyumu Kitabı, Vakıflar Genel Müdürlüğü Yayınları, Ankara 2004, s. 35-47.

Mütevelli, DIA, cilt: 32, 2006, s. 217-220.

ŞİMŞEK, Mehmet, "Osmanlı Cemiyetinde Para Vakıfları Üzerinde Münakaşalar", Ankara Üniversitesi İlahiyat Fakültesi Dergisi, say1: 27/1, s. 207-220.

TURGUT, Bahattin, Urfa Vakıfları (1850-1900), Marmara Üniversitesi Sosyal Bilimler Enst., Doktora Tezi, İstanbul 2013.

TÜRKOĞLU, İrfan " Osmanlı Devletinde Para Vakıflarının Gelir DagIlımı Uzerindeki Etkıleri", Süleyman Demirel Üniversitesi Iktisadi ve idari Bilimler Fakültesi Dergisi, Y. 2013, C. 18, S. 2, s. 187-196.

USTA, Sebahattin, " Trabzon Para Vakıfları", Karadeniz Incelemeleri Dergisi, 2016; (20): 5576.

YAŞAR, Havva Selcen, XIX. Yüzyıl Uşak Para Vakıfları, Dokuz Eylül Üniversitesi Sosyal Bilimler Enstitüsü, Yüksek Lisans Tezi, İzmir 2017.

YEDIYYILDIZ, Bahaeddin, XVIII. Yüzyılda Türkiye'de Vakıf Müessesesi Bir Sosyal Tarih İncelemesi, TTK, Ankara 2003.

"18. Asır Türk Vakıflarının İktisadî Boyutu", Vakıflar Dergisi, sayı: 18, Ankara 1984, s. 5-41.

YÜKSEL, Hasan, "Vakfiyelere Göre Osmanlı Toplumunda Aile", Sosyo Kültürel Değgişme Sürecinde Türk Ailesi, 2, Ankara, 1992, s. 469-470. 


\section{INTERNET KAYNAKLARI}

http://dergipark.gov.tr/download/article-file/226264 Erişim Tarihi: 10. 06. 2017

http://www.vgm.gov.tr/sayfa.aspx?Id=30\#P Erişim Tarihi: 10. 06. 2017

http://www.vgm.gov.tr/sayfa.aspx?Id=30\#P Erişim Tarihi: 10. 06. 2017

http://dergi.altinoluk.com/index.php?sayfa=yillar\&MakaleNo=d058s031m1; Erişim

Tarihi: 10. 06. 2017

http://www.isbek.org/node/vakfiyelerde-dua-ve-beddualar.html Erişim Tarihi: 10. 06. 2017

http://arsiv.diyanetvakfi.org.tr/meal/Bakara.htm Erişim Tarihi: 10. 06. 2017

http://arsiv.diyanetvakfi.org.tr/meal/Aliimran.htm Erişim Tarihi: 10. 06. 2017

http://www.vakar.org/public/files/02.02.2013/vakif-belgeleri.pdf Erişim Tarihi: 10. 06. 2017

http://www.islamveihsan.com/sadaka-i-cariye-nedir.html; Erişim Tarihi: 10. 06. 2017

http://www.isav.org.tr/img/20131030_4127313495.pdf Erişim Tarihi: 10. 06. 2017

http://www.isbek.org/node/vakfiyelerde-dua-ve-beddualar.html; Erişim Tarihi: 10. 06.

2017

http://dergi.altinoluk.com/index.php?sayfa=yillar\&MakaleNo=d053s017m1; Erişim

Tarihi: 10. 06. 2017

http://dergipark.gov.tr/download/article-file/226264; Erişim Tarihi: 10. 06. 2017

ismailkurt.blogcu.com; Erişim Tarihi: 10. 06. 2017

http://www.isam.org.tr/documents/_dosyalar/_pdfler/islam_arastirmalari_dergisi/sayi04

/031_041.pdf Erişim Tarihi: 10. 06. 2017

http://akajans.nl/vakif-kurmanin-puf-noktalari-emre-teker/ Erişim Tarihi: 10. 06. 2017

http://sadakaasondkab.weebly.com/sadaka.html Erişim Tarihi: 10. 06. 2017

http://www.eakademi.org/incele.asp?konu=VAKIFLARIN\%20DEVLET\%20Y\%D6NET\%

DDM\%DDNE\%20KATKILARI\&kimlik=1249334375\&url=makaleler/hertuc-1.htm

Erişim Tarihi: 10. 06. 2017

https://www.tarihtarih.com/?Syf=26\&Syz=382187 Erişim Tarihi: 10. 06. 2017

https://mpra.ub.uni-muenchen.de/73902/1/MPRA_paper_73902.pdf Erişim Tarihi: 10. 06. 2017

http://www.enfal.de/oe84.htm Erişim Tarihi: 10. 06. 2017 
Osmanlı Medeniyeti Araştırmaları Dergisi - Journal of Ottoman Civilization Studies Cilt 1, Sayı, 1, Temmuz 2015, s. 1-9. Sayısında Dr. Yakup Ahbab tarafindan hazırlanan Sonu Gelmeyen Misafirlik: Muhacerat Bosna Muhacirlerinin Kosova'da İskânı başlığıyla yayınlanan makalenin düzeltilmiş hali aşağıda bilgilerinize sunulmuştur.

Sayfa 2, 1. Dipnot: Mahmud Celaleddin Paşa, Mir'ât-i Hakîkat, (Hazırlayan: İsmet Miroğlu), İstanbul 1983, s.677,691; Muammer Demirel, 'Türkiye'de Bosna Göçmenleri'’, s. 286.

Sayfa 2, Dipnot 4: Yusuf Hamza, "Halil Rıfat Paşa’nın Manastır Vilayeti Köylerinin Toplumsal Güvenliği Tüzüğü”, Türk Dünyası Araştırmaları Dergisi, s. 57 (Aralık 1988), s. 170; Muammer Demirel, 'Türkiye'de Bosna Göçmenleri’’, s. 287.

Sayfa 2, 5. Dipnot: Berlin Antlaşması'nı müteakip Bosna-Hersek Avusturya tarafından işgal edilince bu sefer Boşnaklar ocaklarını terk ederek Yenipazar, İşkodra ve Kosova’ya doğru yöneldiler. Babıâli'nin muhalefetine rağmen kısa sürede Kosova, İşkodra ve Makedonya topraklarında binlerce Boşnak göçmeni birikmişti. Keza Kosova Vilayeti Üsküp Sancağı Koçane Kazası dâhilinde Hersek göçmenlerinden 721 kişi iskân işlemi gördü: Başbakanlık Osmanlı Arşivi (BOA), Meclis-i Vükela Mazbataları (MV), no. 69/70; Nedim İpek, "Kosova Vilayeti Dâhilinde Gerçekleşen Göçler”, s. 65-81.

Sayfa 3, 7. Dipnot: Tufan Gündüz, “Bosna’ya Dönen Boşnak Göçmenlerin Türkiye Ve Türkler Hakkındaki Görüşleri’', s. 166-167.

Saya 3, 8. Dipnot; BOA, DH.MKT, no. 2037/35; II. Meşrutiyet'in ilanı sonrasında oluşan siyasi kargaşa sonrasında 5 Ekim 1908 günü Avusturya-Macaristan İmparatorluğu Bosna-Hersek'i topraklarına kattığını ilân etti. Siyasî görüşmeler neticesinde devlet, ilhakı resmen tanıdı. İşgal edilen Yenipazar sancağı geri verildi ve Bosna-Hersek'te kalan mîrî mallar karşılığında Avusturya iki buçuk milyon Osmanlı altını ödemeye razı oldu. Bölgedeki Müslüman nüfus yeniden başta Kosova Vilayeti olmak üzere diğer Osmanlı topraklarına göç etmek zorunda kalmışlardır. Karşılaştıkları zulüm ve baskılardan dolayı Bosna'dan göç edip Kosova Vilayeti'ne gelen Müslüman Boşnakların Rumeli Vilayetlerinin muhtelif yerlerinde iskân edilmeleri meclis-i vükelada görüşülmüştür: $\quad$ BOA, $\quad \mathrm{MV}, \quad$ no. $118 / 10$; http://www.yarseli.com/?Syf=22\&Mkl=448884\&pt=ALINTI\%20YAZI\&Bosna-Hersekin-Kayb\%C4\%B1

Sayfa 4, Dipnot 19; BOA, Makedonya Arşivinden İntikal Eden Evrak Üsküp Muhacirin Komisyonu (MA. ÜSMK), no.25/17-6; 25/19-2; 25/19-5; 25/19-12; Ebubekir Sofuoğlu, 1851-1912 Arası Osmanlı Arşiv Belgelerine Göre Kosova'da Osmanl İdaresi, UKID, İstanbul, s. 140-141; http://www.karam.org.tr/Makaleler/1986089047_003_berber.pdf

Sayfa 5. Dipnot 27: BOA, DH.MKT, no.1479/97; ŞD, no. 1968/10; BOA, DH.MKT, no.1818/24; İrâdeŞurâ-yı Devlet (İ.ŞD), no. 106/6321; Bu tür örnekleri çoğaltmamız mümkündür. Mesela Bursa'da Zeytin Köyüne kırk hane Boşnak yerleştirilmiş ve teşkil edilen köye de Boşnak Köyü ismi verilmişti: BOA, İ.DH, no. 984/77656; Ayrıca bkz. Osmanlı Yönetiminde Makedonya, T.C. Başbakanlık Devlet Arşivleri Genel Müdürlüğü Osmanlı Arşivi Daire Başkanlığı Yayınları, Ankara 2005, s. 30, 20.

Sayfa 5, 29. Dipnot: http://www.zambak.ba/camilerde-suriye8217-ye-yardim-toplanacak-1080h.htm; http://193.255.140.18/Tez/0069688/METIN.pdf; E. Sofuoğlu, age, s. 140; Kasım 1886 tarihinde Kosova'da muhacirler için verilecek zahire kalmadığından bunlar iskân edilinceye kadar mal sandığından büyüklere yirmişer küçüklere onar para yevmiye verilmesi uygun bulunmuştur: BOA,_ _ $D_{-} H_{-} \cdot M_{-} K_{-} T_{-}$, _no.1376/125; Temmuz 1892 tarihinde Üsküp'e bağlı Koçane Kazası Maliş Nahiyesine iskân olan Hersek muhacirlerinin iaşeleri için gönderilen meblağ yetersiz olması üzerine, aradaki farkın Bulgaristan'a firar eden ahalinin bıraktığı arazi üzerindeki mahsulâttan temin edilmiştir: BOA,__D_H_._M_K_T_,_ no.

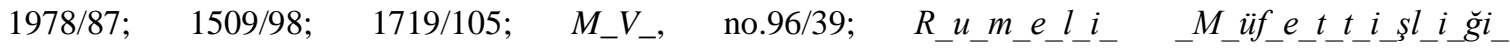
_A_r_z_u_h_a_l_l_e_r_i$\_(\text {- T_F_R_._l_._S K_T })$, no. 10/998. 